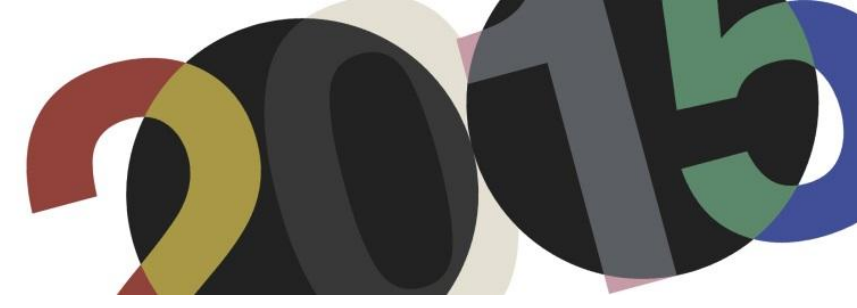

DOI: http://dx.doi.org/10.4995/LC2015.2015.899

\title{
The mur neutralisant as an active thermal system: Saint Gobain tests (1931) versus CFD simulation (2015)
}

\author{
C. Ramírez-Balas*, J.J. Sendra *, R. Suárez*, E.D. Fernández-Nieto**, G. Narbona-Reina** \\ * Instituto Universitario de Arquitectura y Ciencias de la Construcción, Escuela Técnica Superior de \\ Arquitectura, Universidad de Sevilla \\ ** Departamento de Matemática Aplicada I, Escuela Técnica Superior de Arquitectura, Universidad de Sevilla
}

\begin{abstract}
At the same time as the initial development of air conditioning systems for indoor climate control in buildings were occurring in USA, Le Corbusier and Lyon made truly innovative proposals for different projects he was working on in Europe. These served to generate homogenous thermal environments and focused on the combined effect of his mur neutralisant and respiration exacte. The clearest example of their shortcomings is the City of Refuge in Paris (1930-33). Given the technological and economic mistrust towards these proposals, as it was impossible to execute these according to the original plan these were not pursued. CFD simulations carried out by our research team confirm that the mur neutralisant and respiration exacte for the City of Refuge in Paris would have functioned together if they had been executed following the original plans. The main aim of this paper is to confirm the validity of the mur neutralisant as an active thermal system for buildings. Firstly, the results of the tests carried out by the engineers of Saint Gobain are compared to the results of the CFD simulations. Based on the comparison of the results from the physical models tested in Saint Gobain laboratories and CFD energy model simulations, a possible calibration is proposed for CFD which might prompt the establishment of other operation hypotheses.
\end{abstract}

Keywords: Le Corbusier; mur neutralisant; The City of Refuge; Active Façade System; Computational Fluid Dynamics (CFD); Numerical Simulation.

\section{Introduction}

In the 20th century, air conditioning systems gained success first in the United States and then in Europe, and their use became increasingly widespread throughout the century. In contrast, the proposals from Le Corbusier and Lyon, based on the combination of the mur neutralisant and respiration exacte (figure 1) as an active thermal system, only provoked technical and financial mistrust so that they were not followed up and could not be executed as planned. However, in the late 20th century these reappeared as predecessors of active façade systems. The best-known example of their failure is the City of Refuge in Paris (1930-33), designed as Salvation Army accommodation for between 500 and 600 homeless people.

However, simulations carried out by our research team using Computational Fluid Dynamics (CFD) programs confirm the combined effect of the mur neutralisant and respiration exacte on the temperature control of the main dormitory in the City of Refuge of Paris if the system had been executed following the original designs of Le Corbusier and Lyon ${ }^{1}$. The main aim of this study is to establish the suitability of the mur neutralisant as an active conditioning system for buildings. In the 1930s Saint Gobain engineers Lebel and Le Barbier carried out

\footnotetext{
${ }^{1}$ Ramírez Balas, C.; Fernández Nieto, E.D.; Narbona Reina,G.; Sendra, J. J.; Suárez, R. "Numerical simulation of the temperature evolution in a room with a mur neutralisant. Application to 'The City of Refuge' by Le Corbusier". Energy and buildings. 2015. 86. pp. 708-722.
} 
laboratory tests on physical models to ascertain the suitability of the mur neutralisant as an active heating system in extreme outdoor temperatures and without solar radiation ${ }^{234}$. Our research group has compared these with the results obtained in 2015 using energy models and CFD simulations of the same operation and outdoor environmental conditions.

Following the comparison and adjustment of both models, other hypotheses have been established regarding the operation of the energy models and subsequent CFD simulation of the design of a south-facing mur neutralisant for the main dormitory in the City of Refuge. The operation of the mur neutralisant has been assessed as an active heating system for cold winter days with and without sunlight, including the influence of solar radiation, which was neglected in the Saint Gobain tests, and as an active cooling system on hot summer days, an operation mode which Saint Gobain also failed to test.

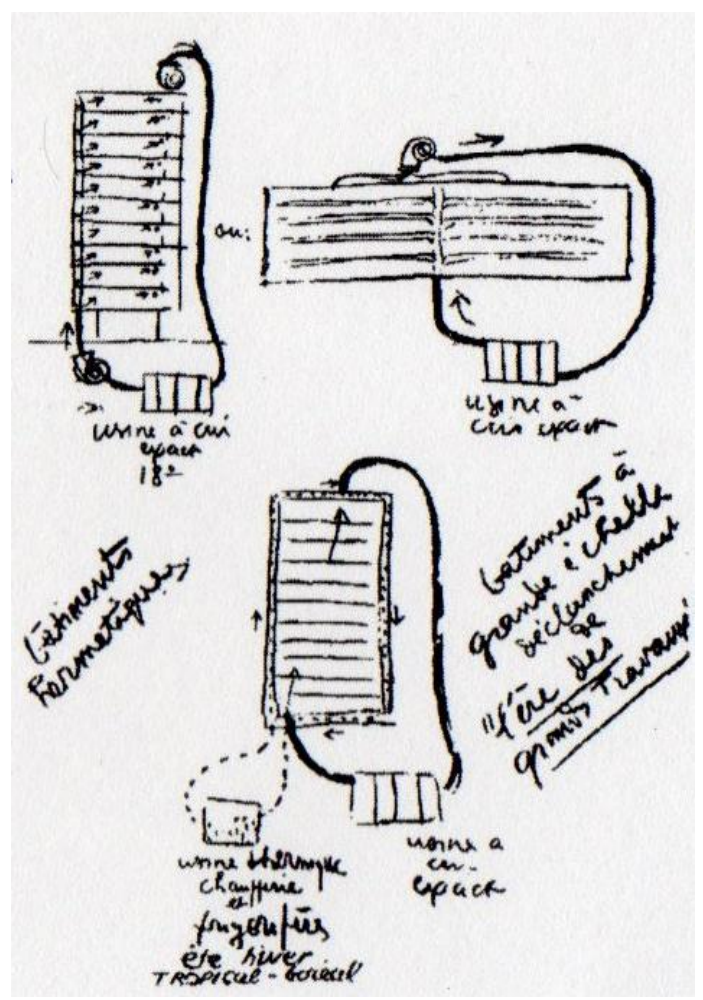

1a. Diagram by Le Corbusier of the operation of the mur neutralisant ${ }^{6}$.

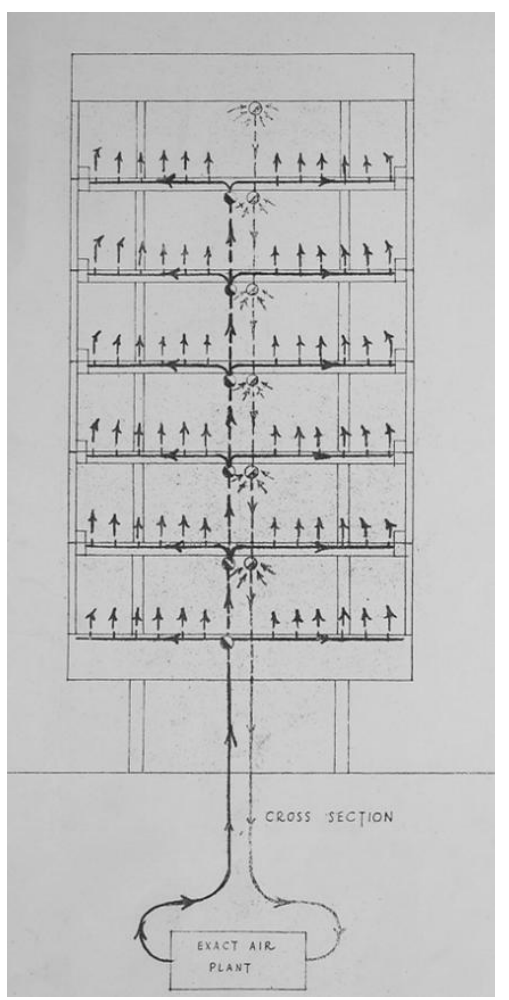

1b. Drawing by Le Corbusier of the mur neutralisant and respiration exacte ${ }^{7}$.

1. Proposal by Le Corbusier for the mur neutralisant and respiration exacte.

\footnotetext{
${ }^{2}$ Le Braz, J. "La transmission de la chaleur gràverâ travers le verre: Des idées nouvelles sur le chauffage des habitations." Glaces et Verres. 1933. № 20. pp. 13.

${ }^{3}$ Brian Brace, T. "Le Corbusier, the city of refuge, Paris 1929-33". Chicago: University of Chicago Press. 1987.

${ }^{4}$ Cuadernos de Postgrado. La respuesta de la American Blower Corporation. 24 January 1930.

5 Bryan, Harvey. "Le Corbusier and the 'Mur Neutralisant': An Early Experiment in Double Envelope Construction." Proceedings of the Ninth International PLEA Conference. 1991. pp. 257-62.

${ }^{6}$ Le Corbusier. El edificio hermético. "Croquis de Précisions".

${ }^{7}$ Foundation Le Corbusier. FLC 15720. (FLC-ADAGP.
} 


\section{Saint Gobain tests}

On Le Corbusier's instructions, Saint Gobain engineers carried out numerous tests over a two-year period, recording them in two documents on 25 June $1931^{8}$ and 11 March $1932^{9}$.

The test room (figure 2) consisted of two rooms with a $0.5 \mathrm{~m}$ intermediate space and $7 \mathrm{~mm}$ double glazing in a wooden frame with an air cavity varying between 3 and $20 \mathrm{~cm}$ in width. The room known as the hot room representing the interior space, measured $2.04 \times 1.64 \mathrm{~m}$ and was $2.72 \mathrm{~m}$ high. It needed to maintain an indoor temperature of $18{ }^{\circ} \mathrm{C}$ to ensure minimum thermal comfort conditions in winter. Another "cold" room, measuring $0.8 \times 1.4 \mathrm{~m}$ and $2.4 \mathrm{~m}$ high, represented the outdoor space. The temperature in this cold room could be maintained at different low winter levels.

Walls, ceilings and floors were built using $12 \mathrm{~cm}$ thick expanded cork insulation panels in the hot room, while those used in the cold room were $24 \mathrm{~cm}$ thick. On two of these walls the panels were in contact with a brick enclosure. All openings were sealed and a $22 \times 22 \mathrm{~cm}$ window (K) was used to review the installation without opening the door. Figure 2 shows the following elements: a $2.5 \mathrm{~m}$ long conduct, used to measure the fan-driven airflow, which varied between 0 and $150 \mathrm{l} / \mathrm{s}$; an air heater consisting of a series of electric resistances which could bring the temperature up to $50^{\circ} \mathrm{C}$; a device consisted of a shell with holes on top, placed at the bottom of the air cavity between both glass panes and distributing air inside the cavity. The hot air passing between both glass sheets was expelled through a hole at the top of the air cavity. Finally, four temperature sensors were placed: (a) at the centre of the hot room; (b) at the centre of the cold room, $1.22 \mathrm{~m}$ from the glass; (c) in the hot air conduct, prior to air entry to the cavity; and (d) at hot air outlet, at the top of the air cavity.
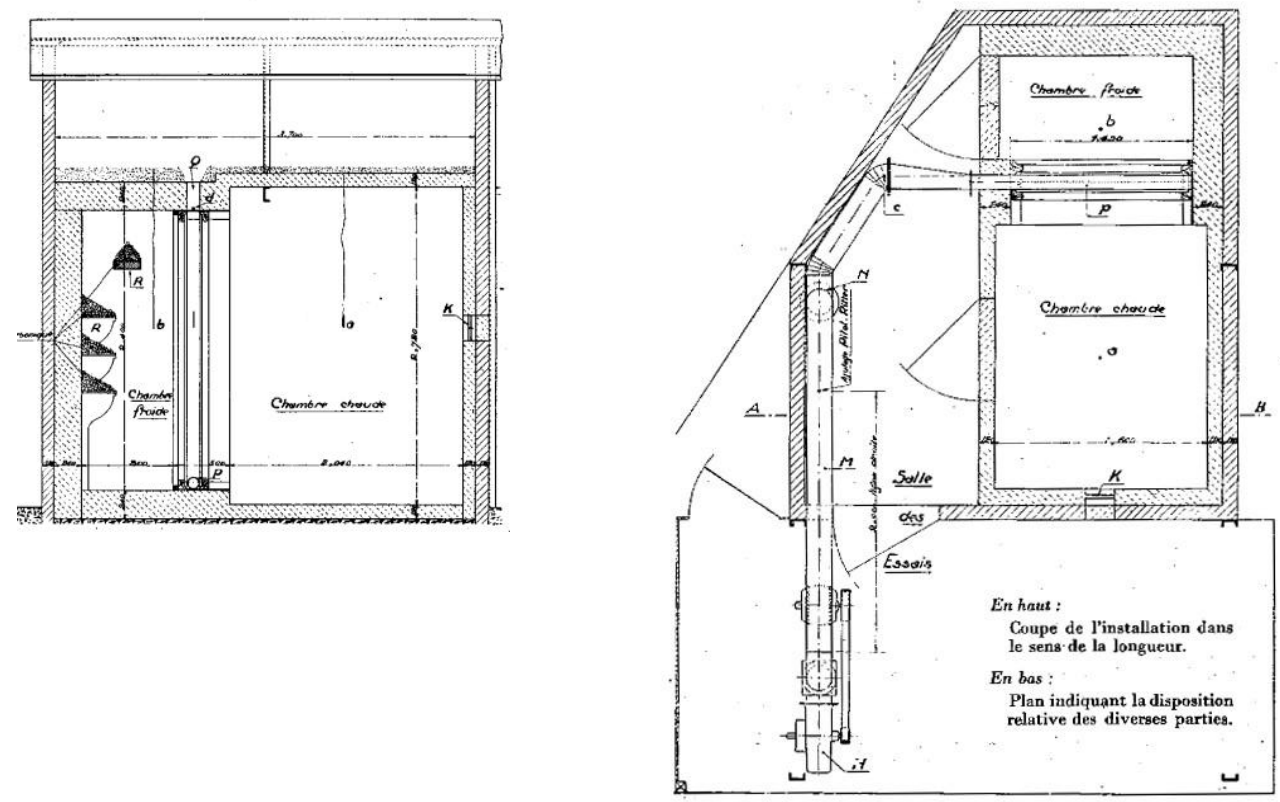

2. Horizontal and vertical section of the Saint Gobain test room ${ }^{10}$.

\footnotetext{
${ }^{8}$ Lebel, H.; Le Barbier, M. Société Anonyme des Manufactures des Glaces et Produits Chimiques de Saint-Gobain, Chauny et Cirey. Note sur les essais de transmission de la chaleur à travers les glaces, efectués à l'Annexe du Comptoir de Vente, 23 rue Boucry, Paris du 3 Avril au 8 Mai 1931. Letter of 25 June 1931.

${ }^{9}$ Lebel H.; Le Barbier, M. Société Anonyme des Manufactures des Glaces et Produits Chimiques de Saint-Gobain, Chauny et Cirey. Note sur la seconde série d'essais effectués pour la mesure de la transmission de la chaleur à travers les glaces à l'Annexe du Comptoir de Vente, 23 rue Boucry, Paris du 23 Novembre au 21 Décembre 1931. Letter of 11 March 1932.
} 
Various tests proposing different hypotheses were carried out on a $7 \mathrm{~mm}$ double glazed mur neutralisant. The width of the air cavity, airflow and duration of the test were modified. The main aim was to obtain a low transmission coefficient $(\mathrm{Q})$ for the mur neutralisant in winter with a view to maintaining an indoor room temperature of $18^{\circ} \mathrm{C}$ in very low outdoor temperatures with no solar radiation.

Between 3 April and 8 May 1931 an initial series of tests was carried out for three air cavity widths: $20 \mathrm{~mm}, 70$ $\mathrm{mm}$ and $120 \mathrm{~mm}$, with no hot airflow through the cavity (table 1). The Q values obtained were 2.80, 3.36 and $3.92 \mathrm{kcal} / \mathrm{h} \mathrm{m}^{2}{ }^{\circ} \mathrm{C}$, respectively. Accordingly, the decision was made to continue the tests with a hot airflow of $100 \mathrm{l} / \mathrm{s}$ into the air cavity (active chamber), at different temperatures and cavity widths between 11 and $12 \mathrm{~cm}$. An initial run of three tests on the $12 \mathrm{~cm}$ active chamber was carried out with different airflow temperatures suited to the cold room temperature (case 1, table 2), followed by a second three-test run with the same airflow, varying the cavity widths to $11 \mathrm{~cm}$ (case 2, table 3), and with cold room and hot airflow temperatures also differing from earlier ones. In both cases the hypotheses were numbered following the chronological order of tests.

\begin{tabular}{|l|c|c|c|}
\hline & 13 April & 15 April & 14 April \\
\hline Test duration & $2 \mathrm{~h} \mathrm{30}$ & $2 \mathrm{~h} 45^{\prime}$ & $2 \mathrm{~h} \mathrm{30}$ \\
\hline Active chamber width & $12 \mathrm{~cm}$ & $7 \mathrm{~cm}$ & $2 \mathrm{~cm}$ \\
\hline Mean T hot room: Tc & $+18^{\circ} \mathrm{C}$ & $+18^{\circ} \mathrm{C}$ & $+18^{\circ} \mathrm{C}$ \\
\hline Mean T cold room: Tf & $-7.5^{\circ} \mathrm{C}$ & $-22.5^{\circ} \mathrm{C}$ & $-15.5^{\circ} \mathrm{C}$ \\
\hline Mean ambient T: Ta & $+12.8^{\circ} \mathrm{C}$ & $+13^{\circ} \mathrm{C}$ & $+12.2^{\circ} \mathrm{C}$ \\
\hline Value of Q $\left(\mathrm{kcal}^{\prime} / \mathrm{hm}^{20} \mathrm{C}\right)$ & 2.80 & 3.36 & 3.92 \\
\hline
\end{tabular}

Table 1. Tests on mur neutralisant with different chamber widths and no heating.

\begin{tabular}{|l|c|c|c|}
\hline Case 1: $12 \mathrm{~cm}$ & Hypothesis 1 & Hypothesis 2 & Hypothesis 3 \\
\hline & 27 April & 28 April & 29 April \\
\hline Test duration & $1 \mathrm{~h} 30^{\prime}$ & $1 \mathrm{~h} 15^{\prime}$ & $2 \mathrm{~h} 45^{\prime}$ \\
\hline Active chamber width & $12 \mathrm{~cm}$ & $12 \mathrm{~cm}$ & $12 \mathrm{~cm}$ \\
\hline Mean T hot room: Tc & $+19^{\circ} \mathrm{C}$ & $+16.2^{\circ} \mathrm{C}$ & $+16^{\circ} \mathrm{C}$ \\
\hline Mean T cold room: Tf & $-6^{\circ} \mathrm{C}$ & $-8.8^{\circ} \mathrm{C}$ & $-17.5^{\circ} \mathrm{C}$ \\
\hline Mean ambient T: Ta & $+14^{\circ} \mathrm{C}$ & $+15^{\circ} \mathrm{C}$ & $+13.5^{\circ} \mathrm{C}$ \\
\hline Inlet T mur neutralisant & $+20.25^{\circ} \mathrm{C}$ & $+20.2^{\circ} \mathrm{C}$ & $+22.7^{\circ} \mathrm{C}$ \\
\hline Outlet T mur neutralisant & $+17.5^{\circ} \mathrm{C}$ & $+16.5^{\circ} \mathrm{C}$ & $+17.5^{\circ} \mathrm{C}$ \\
\hline Airflow & $1001 / \mathrm{s}$ & $1001 / \mathrm{s}$ & $1001 / \mathrm{s}$ \\
\hline Value of Q $\left(\mathrm{kcal} / \mathrm{hm}^{\circ} \mathrm{C}\right)$ & 5.95 & 6.78 & 6.70 \\
\hline
\end{tabular}

Table 2. Test on 7+120+7 mm mur neutralisant with hot airflow inside the active chamber and with the same flow.

\begin{tabular}{|l|c|c|c|}
\hline Case 2: $11 \mathrm{~cm}$ & Hypothesis 1 & Hypothesis 2 & Hypothesis 3 \\
\hline & $8 \mathrm{May}$ & $8 \mathrm{May}$ & $8 \mathrm{May}$ \\
\hline Test duration & $50^{\prime}$ & $4 \mathrm{~h} 15^{\prime}$ & $55^{\prime}$ \\
\hline Active chamber width & $11 \mathrm{~cm}$ & $11 \mathrm{~cm}$ & $11 \mathrm{~cm}$ \\
\hline Mean T hot room: Tc & $+18^{\circ} \mathrm{C}$ & $+18^{\circ} \mathrm{C}$ & $+18^{\circ} \mathrm{C}$ \\
\hline Mean T cold room: Tf & $-28^{\circ} \mathrm{C}$ & $-20^{\circ} \mathrm{C}$ & $-13^{\circ} \mathrm{C}$ \\
\hline Mean ambient T: Ta & $17^{\circ}$ & $17^{\circ}$ & $17^{\circ}$ \\
\hline Inlet T mur neutralisant & $+38^{\circ} \mathrm{C}$ & $+31.5{ }^{\circ} \mathrm{C}$ & $+27.5^{\circ} \mathrm{C}$ \\
\hline Outlet T mur neutralisant & $+28.5^{\circ} \mathrm{C}$ & $+24^{\circ} \mathrm{C}$ & $+22{ }^{\circ} \mathrm{C}$ \\
\hline Airflow & $1001 / \mathrm{s}$ & $1001 / \mathrm{s}$ & $1001 / \mathrm{s}$ \\
\hline Value of Q $\left(\mathrm{kcal} / \mathrm{hm}^{2 \circ} \mathrm{C}\right)$ & 6.60 & 7.00 & 6.60 \\
\hline
\end{tabular}

Table 3. Test on 7+110+7 mmmur neutralisant with hot airflow inside the active chamber and with the same flow.

${ }^{10} \mathrm{Le}$ Braz, J. "La transmission de la chaleur gràverâ travers le verre: Des idées nouvelles sur le chauffage des habitations". Glaces et Verres. 1933. № 20. pp. 13. 
Between 23 November and 21 December another three tests were carried out with different flows and hot airflow temperatures in the $12 \mathrm{~cm}$ active chamber, depending on the temperature of the cold room (case 1, table 4).

\begin{tabular}{|l|c|c|c|}
\hline Case 1: $12 \mathrm{~cm}$ & Hypothesis 4 & Hypothesis 5 & Hypothesis 6 \\
\hline & 26 November & 18 December & 18 December \\
\hline Test duration & $1 \mathrm{~h}$ & $1 \mathrm{~h} 30^{\prime}$ & $1 \mathrm{~h} 45^{\prime}$ \\
\hline Active chamber width & $12 \mathrm{~cm}$ & $12 \mathrm{~cm}$ & $12 \mathrm{~cm}$ \\
\hline Mean T hot room: Tc & $+17.2^{\circ} \mathrm{C}$ & $+18.1^{\circ} \mathrm{C}$ & $+18^{\circ} \mathrm{C}$ \\
\hline Mean T cold room: Tf & $-11.5^{\circ} \mathrm{C}$ & $-11.8^{\circ} \mathrm{C}$ & $-10.5^{\circ} \mathrm{C}$ \\
\hline Mean ambient T: Ta & $+13^{\circ} \mathrm{C}$ & $+7.5^{\circ} \mathrm{C}$ & $+8^{\circ} \mathrm{C}$ \\
\hline Inlet T mur neutralisant & $+35.7^{\circ} \mathrm{C}$ & $+35.5^{\circ} \mathrm{C}$ & $+43.7^{\circ} \mathrm{C}$ \\
\hline Outlet T mur neutralisant & $+29.2^{\circ} \mathrm{C}$ & $+29.7^{\circ} \mathrm{C}$ & $+32.5^{\circ} \mathrm{C}$ \\
\hline Airflow & $150 \mathrm{l} / \mathrm{s}$ & $1201 / \mathrm{s}$ & $85 \mathrm{l} / \mathrm{s}$ \\
\hline Valueof Q (kcal/hm $\left.{ }^{2 \circ} \mathrm{C}\right)$ & 6.98 & 6.34 & 5.35 \\
\hline
\end{tabular}

Table 4. Test on 7+120+7 mm mur neutralisant with hot airflow inside the active chamber and with different flows.

On 12 December 1931 a test was carried out using an electric radiator inside the $13 \mathrm{~cm}$ cavity in order to determine the influence of hot air convection within this active chamber (case 3 , table 5).

\begin{tabular}{|l|c|}
\hline Case 3: $13 \mathrm{~cm}$ & 12 December \\
\hline Test duration & $1 \mathrm{~h} 30^{\prime}$ \\
\hline Active chamber width & $13 \mathrm{~cm}$ \\
\hline Mean T hot room: Tc & $+18.5^{\circ} \mathrm{C}$ \\
\hline Mean T cold room: Tf & $-10.2^{\circ} \mathrm{C}$ \\
\hline Mean ambient T: Ta & $+2.7^{\circ} \mathrm{C}$ \\
\hline Mean T cavity & $+42.1^{\circ} \mathrm{C}$ \\
\hline Value of Q $\left(\mathrm{kcal} / \mathrm{hm}^{2 \circ} \mathrm{C}\right)$ & 5.49 \\
\hline
\end{tabular}

Table 5. Test on 7+130+7 mm mur neutralisant with intermediate heating from electric radiator.

Finally, in late 1931 a further two tests were executed with a mur neutralisant configuration consisting of three 7 $\mathrm{mm}$ panes, with a $65 \mathrm{~mm}$ separation between the outer glazing and the intermediate glazing, and $120 \mathrm{~mm}$ between the intermediate and the inner glazing, with no hot airflow in the two air chambers (table 6).

\begin{tabular}{|l|c|c|}
\hline & 1 December & 16 December \\
\hline Test duration & $1 \mathrm{~h} 26^{\prime}$ & $2 \mathrm{~h} \mathrm{3}$ \\
\hline Width of cavity between inner glazing and intermediate glazing & $12 \mathrm{~cm}$ & $12 \mathrm{~cm}$ \\
\hline Width of cavity between intermediate glazing and outer glazing & $6.5 \mathrm{~cm}$ & $6.5 \mathrm{~cm}$ \\
\hline Mean T hot room: Tc & $+17.6^{\circ} \mathrm{C}$ & $+18^{\circ} \mathrm{C}$ \\
\hline Mean T cold room: Tf & $-10.9^{\circ} \mathrm{C}$ & $-11.5^{\circ} \mathrm{C}$ \\
\hline Mean ambient T: Ta & $+6.2^{\circ} \mathrm{C}$ & $+7.4^{\circ} \mathrm{C}$ \\
\hline Value of Q $\left(\mathrm{kcal} / \mathrm{hm}^{2 \circ} \mathrm{C}\right)$ & 1.65 & 1.71 \\
\hline
\end{tabular}

Table 6. Tests on 7+65+7+120+7 mm mur neutralisant without heating.

\section{Numerical model proposed for the simulation of the mur neutralisant}

Current CFD energy simulation systems make it possible to evaluate the energy behaviour of the mur neutralisant solution proposed by Le Corbusier. In fact, our research group has developed a CFD model not only reproducing the behaviour of Le Corbusier's mur neutralisant, but also its behaviour when combined with 
respiration exacte ${ }^{11}$. The numerical calculation model drawn up using mathematical codes and ways of resolution was implemented and subsequently simulated using FreeFem++ (hereafter FF++) ${ }^{12}$.

Figure 3 clearly shows the energy flows within the mur neutralisant, which were taken into account in the design of the model. Of the total incident solar radiation $\left(\mathrm{I}_{\mathrm{o}}\right), 7 \%$ was reflected to the exterior $\left(\xi_{\mathrm{eg}}\right)$ and $14 \%$ absorbed by the outer glazing $\left(\alpha_{\mathrm{eg}}\right)$. The remaining $79 \%$ of energy incides on the inner glazing $\left(\tau_{\mathrm{eg}}\right)$, with $7 \%$ transmitted to the air cavity through reflection $\left(\xi_{\mathrm{ig}}\right), 14 \%$ absorbed by the inner glazing $\left(\alpha_{\mathrm{ig}}\right)$ and finally, $58 \%$ of incident solar energy which is transmitted to the room $\left(\tau_{\mathrm{ig}}\right)$.

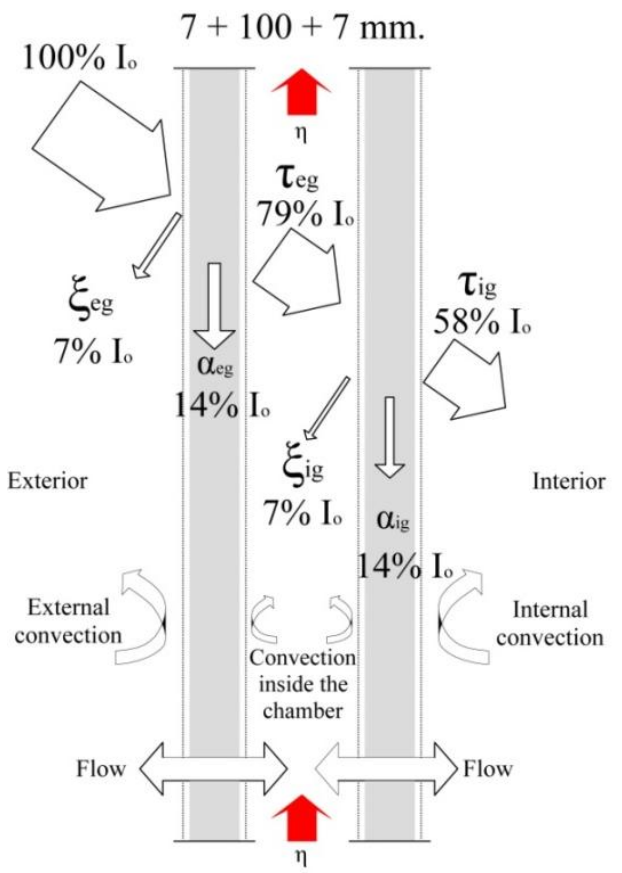

3. Scope and detail of physical phenomena in the mur neutralisant.

The numerical model proposed resolves the following system of partial differential equations:

$$
\left\{\begin{array}{c}
(\rho c V)_{f} \frac{\partial T_{f}}{\partial z}=-\eta c \frac{\partial T_{f}}{\partial z}+U_{c} A\left(T_{e g}-T_{f}\right)+U_{c} A\left(T_{i g}-T_{f}\right) \\
(\rho c V)_{e g} \frac{\partial T_{e g}}{\partial t}=U_{e x t} A\left(T_{e x t}-T_{e g}\right)+U_{c} A\left(T_{f}-T_{e g}\right)+\sigma \varepsilon_{e g}\left(T_{e x t}^{4}-T_{e g}^{4}\right)+\alpha_{e g} I_{o}+Q_{e g} \\
(\rho c V)_{i g} \frac{\partial T_{i g}}{\partial t}=U_{i n t} A\left(T_{i n t}-T_{i g}\right)+U_{c} A\left(T_{f}-T_{i g}\right)+\sigma \varepsilon_{i g}\left(T_{i n t}^{4}-T_{i g}^{4}\right)+\alpha_{i g} \tau_{e g} I_{o}+Q_{i g}
\end{array}\right.
$$

with $z \in[0, L], \mathrm{L}$ is the length of the mur neutralisant and $t \in\left[\mathrm{t}_{0}, \mathrm{t}_{\mathrm{M}}\right]$ time.

\footnotetext{
${ }^{11}$ Ramírez Balas, C.; Fernández Nieto, E.D.; Narbona Reina,G.; Sendra, J.J.; Suárez, R. "Numerical simulation of the temperature evolution in a room with a mur neutralisant. Application to 'The City of Refuge' by Le Corbusier". Energy and buildings. 2015. Vol. 86. pp. 708-722.

${ }^{12}$ FreeFem++ v.-3.37-1. Available from: http://www.FreeFem.org/ff++/ (22.05.15).
} 
The model designed can calculate in both winter and summer conditions as it makes it possible to introduce the absorption, transmission and reflection of solar radiation and the convection flows in the glazing due to incidence of solar radiation and exterior temperature.

The model was validated with the models proposed by Ismail and Henríquez ${ }^{131415}$. This research focused exclusively on the study of the effects of the mur neutralisant. The complete development of the numerical model can be consulted in ${ }^{16}$.

\section{Numerical model vs. Saint Gobain tests}

The initial proposal was the comparison of the results of the 1930s Saint Gobain tests (hereafter SG) with the FF++ simulation results of the Computational Fluid Dynamics numerical models design (hereafter CFD), with only the mur neutralisant in operation.

The CFD model reproduces the Saint Gobain test room, respecting the measurements and characteristics of the room and the mur neutralisant under study (Fig. 4). The mesh density in the CFD model was adjusted to ensure reliable results and a minimum margin of error (Fig. 5).

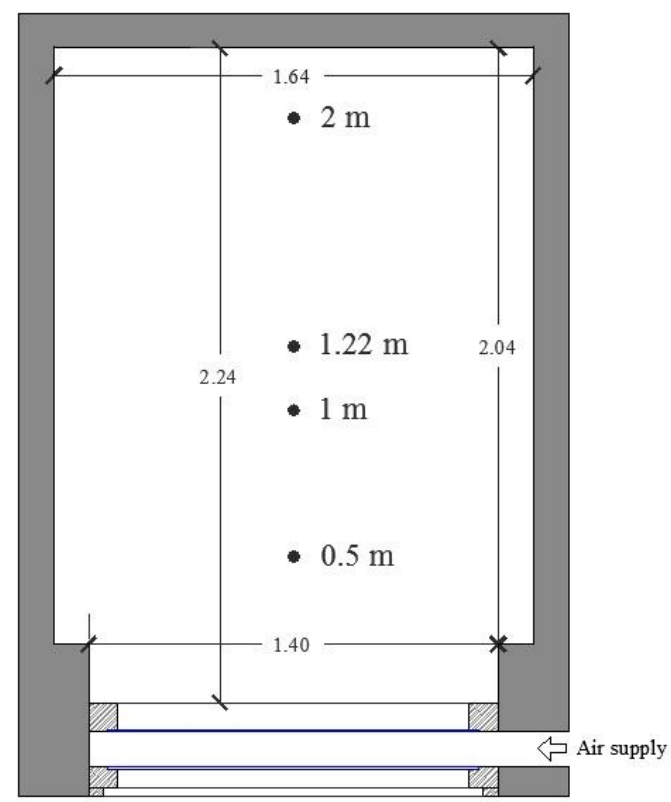

4. Dimensions and points of measurement for the SG room.

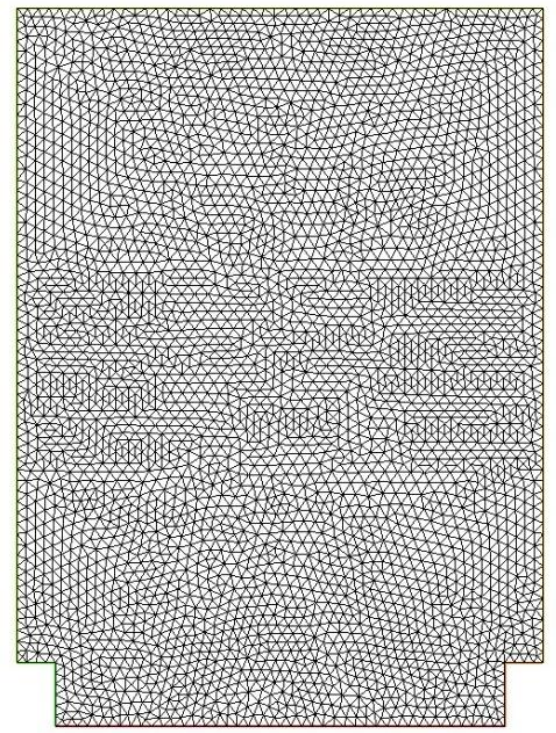

5. Density of the SG room mesh for CFD model.

\footnotetext{
${ }^{13}$ Ismail, K.A.R.; Henríquez, J.R. "Modeling and simulation of a simple glass window", Solar Energy Materials \& Solar Cells. 2003. 80. pp. 355-374.

${ }^{14}$ Ismail, K.A.R.; Henríquez, J.R. "Two-dimensional model for the double glass naturally ventilated window", International Journal of Heat and Mass Transfer. 2005. 48. pp. 461-475.

${ }^{15}$ Ismail, K.A.R.; Henríquez, J.R. "Simplified model for a ventilated glass window under forced air flow conditions". Applied Thermal Engineering. 2006. 26. pp. 295-302.

${ }^{16}$ Ramírez Balas, C.; Fernández Nieto, E.D.; Narbona Reina,G.; Sendra, J. J.; Suárez, R. "Numerical simulation of the temperature evolution in a room with a mur neutralisant. Application to 'The City of Refuge' by Le Corbusier". Energy and buildings. 2015. 86. pp. 708-722.
} 
Test 2, with a 7+110+7 mm mur neutralisant in the Saint Gobain hypothesis, was taken as reference for the comparison of the results of both models for two main reasons. It was the test with the longest duration, $4 \mathrm{~h} 15$ $\mathrm{m}$, to maintain the room at $18{ }^{\circ} \mathrm{C}$ and it established an air flow of $100 \mathrm{l} / \mathrm{s}$ in the chamber. Saint Gobain established this value after analysing the effect of different flows, such as $120 \mathrm{l} / \mathrm{s}$ and $150 \mathrm{l} / \mathrm{s}$. It was shown that with the reduction of airflow to $100 \mathrm{l} / \mathrm{s}$ there was a considerable reduction in the heat transmission coefficient due to less turbulence in the air chamber and less active exchanges between the hot air and the cold outer glazing.

Table 7 shows the results of the CFD model simulation at hourly intervals from the first to the fourth hour, recording the evolution of the different temperatures both in the room and the mur neutralisant itself. As with the SG model, the simulation was carried out in the absence of solar radiation. In addition, figure 6 shows the output of the results of the CFD model for the same hourly intervals. Based on these results, a graph was produced to show the distribution of the indoor room temperature in relation to the room depth (Fig. 7).

\begin{tabular}{|l|c|c|c|c|c|}
\cline { 3 - 7 } \multicolumn{2}{c|}{} & \multicolumn{5}{c|}{ Test duration FF++ (CFD) } \\
\hline Room under study & $60 \mathrm{~min}$ & $120 \mathrm{~min}$ & $180 \mathrm{~min}$ & $240 \mathrm{~min}$ \\
\hline $0.5 \mathrm{~m}$ Room temperature & T $0.5 \mathrm{~m}$ & 20.15 & 21.50 & 22.29 & 22.74 \\
\hline $1 \mathrm{~m}$ Room temperature & T $1 \mathrm{~m}$ & 18.82 & 19.35 & 19.65 & 19.82 \\
\hline $1.22 \mathrm{~m}$ Room temperature & T $1.22 \mathrm{~m}$ & 18.53 & 18.87 & 19.07 & 19.18 \\
\hline $2 \mathrm{~m}$ Room temperature & T $2 \mathrm{~m}$ & 18.07 & 18.12 & 18.15 & 18.16 \\
\hline Mur neutralisant & & $60 \mathrm{~min}$ & $120 \mathrm{~min}$ & $180 \mathrm{~min}$ & $240 \mathrm{~min}$ \\
\hline Exterior glazing temperature & Teg & -3.38 & 3.76 & 6.41 & 7.41 \\
\hline Interior glazing temperature & Tig & 21.89 & 25.24 & 27.10 & 28.47 \\
\hline
\end{tabular}

Table 7. Temperatures of the room and mur neutralisant following CFD simulations with air heating.

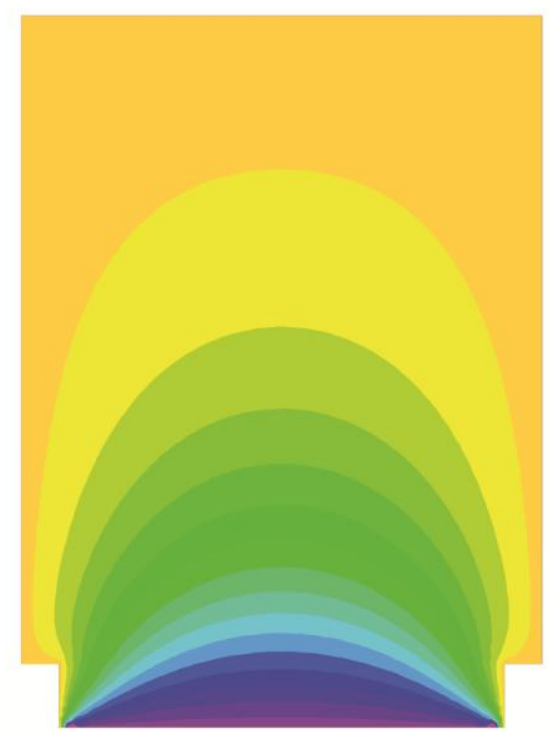

6a. $60 \mathrm{~min}$

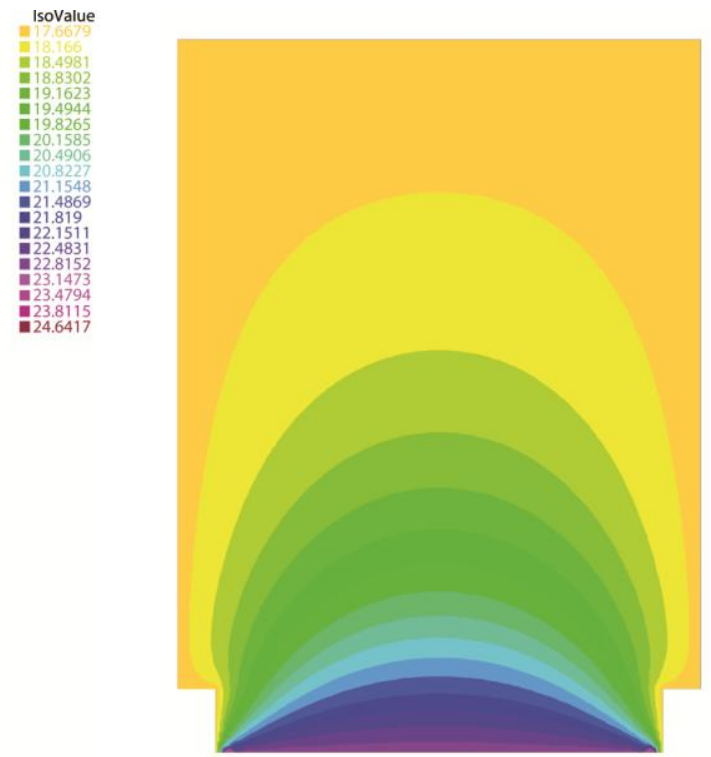

6b. $120 \mathrm{~min}$. 


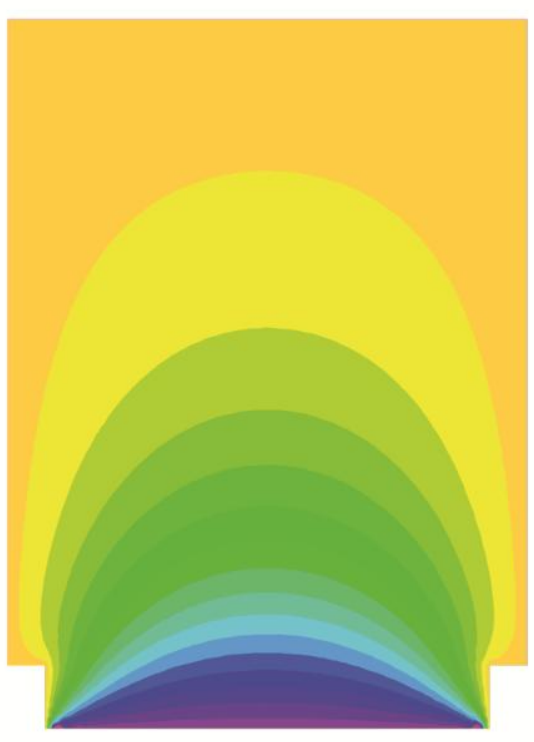

6c. $180 \mathrm{~min}$.
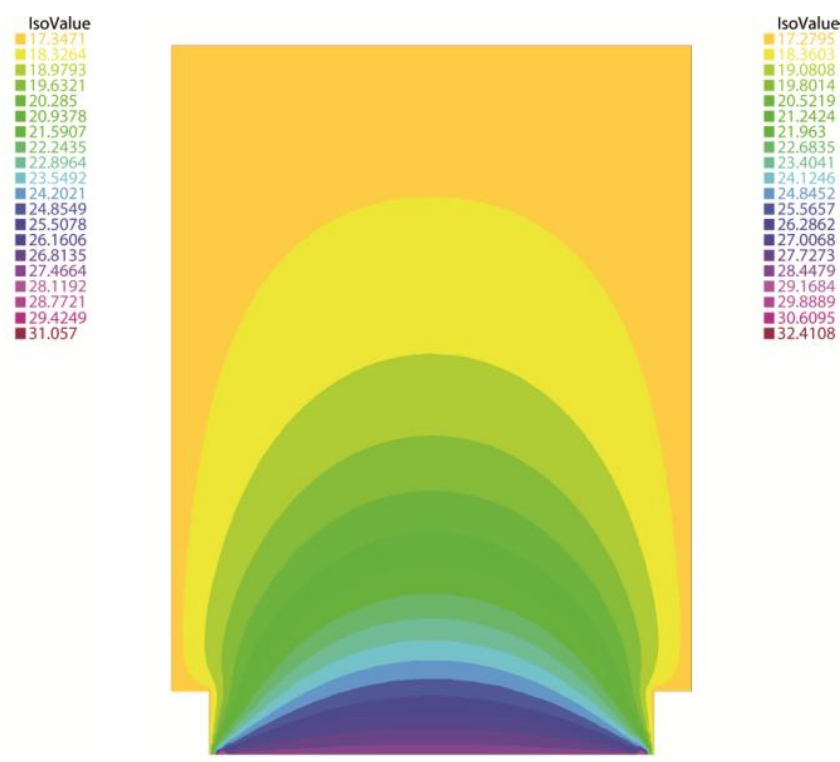

6d. $240 \mathrm{~min}$.

6. Results of the CFD simulation at hourly intervals (horizontal model section) with air heating.

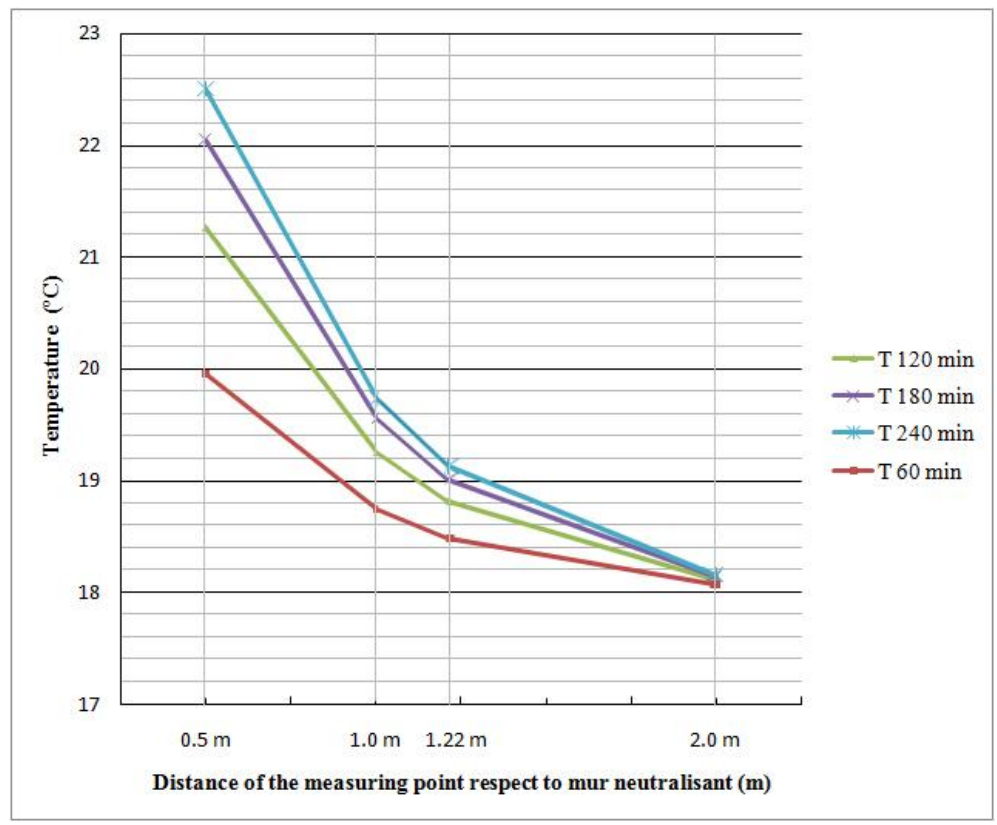

7. Evolution of indoor temperature at different points of the room over 4 hours with air heating.

Figure 7 shows that with the same flow temperature in the active chamber as the SG model, $31.5^{\circ} \mathrm{C}$, and the mass flow from the same airflow in the chamber, $100 \mathrm{l} / \mathrm{s}$, the temperature $1.22 \mathrm{~m}$ deep where Saint Gobain placed temperature probes is around $19^{\circ} \mathrm{C}$, a degree higher than that of SG. Convergence at $18{ }^{\circ} \mathrm{C}$ takes place 2 $\mathrm{m}$ from the mur neutralisant. Therefore, with this temperature and flow the values occurring in the room are similar to those Saint Gobain regarded as comfort level in winter, or even slightly higher. 
As is to be expected the indoor and outdoor surface temperature of the glazing in the mur neutralisant evolve over time, increasing perceptibly to values around $7^{\circ} \mathrm{C}$ outdoors and $28.4{ }^{\circ} \mathrm{C}$ indoors. Therefore, given that the difference in temperature between both models is around $5 \%$, it can be considered that in winter conditions without solar radiation there is adjustment between them.

\section{Establishment of other hypotheses on environmental conditions and the operation of the mur neutralisant}

Once the adjustment between both models was established, different hypotheses were proposed for environmental and operation conditions of the mur neutralisant, but the CFD model of the test room was replaced with a model of the main dormitory of the City of Refuge (figure 8) (hereafter CR model), with a surface area of $297.67 \mathrm{~m}^{2}$. Figure 9a shows this model and figure $9 \mathrm{~b}$ shows the meshing applied to it. The southfacing façade of the Parisian CR model is a mur neutralisant $37.20 \mathrm{~m}$ long and $2.80 \mathrm{~m}$ high, with a surface area of $104.16 \mathrm{~m}^{2}$ and a $110 \mathrm{~mm}$ cavity with $7 \mathrm{~mm}$ double glazing $(7+110+7)$.

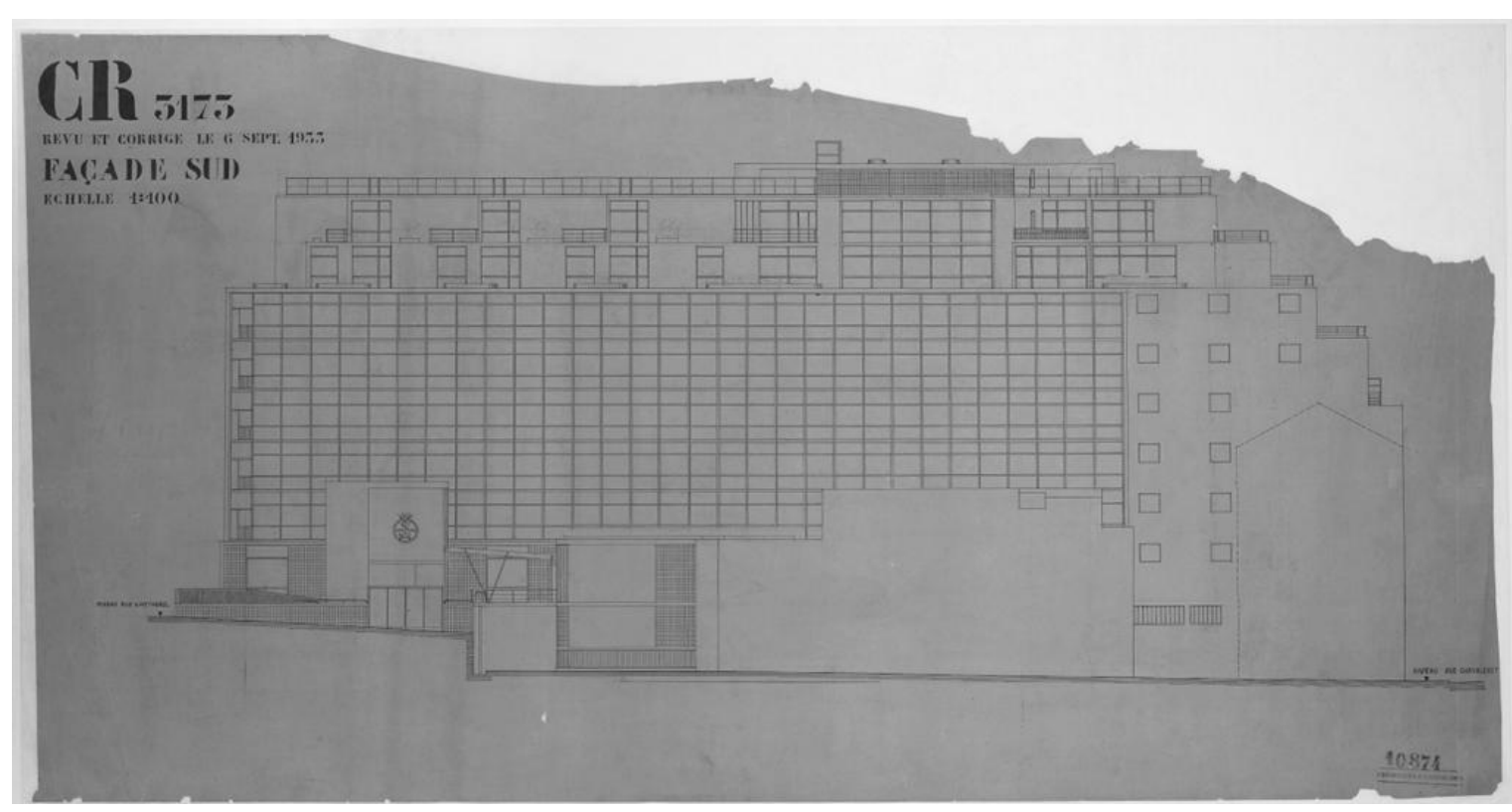

8a. South façade of the City of Refuge ${ }^{17}$.

\footnotetext{
${ }^{17}$ Fundation Le Corbusier. CR 3173. FLC 10874. OFLC-ADAGP
} 


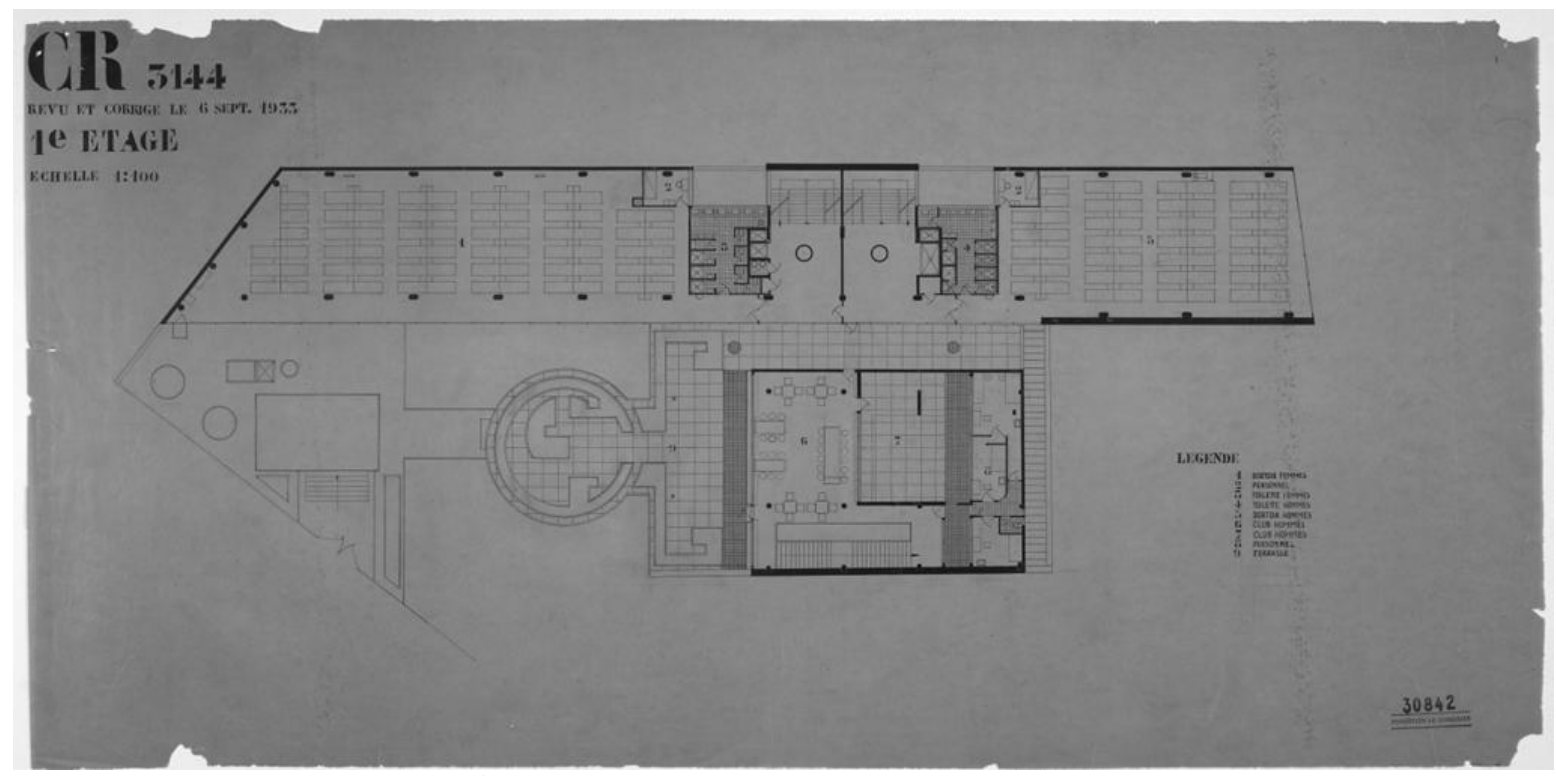

8 b. First floor of the City of Refuge ${ }^{18}$.

8. Drawings of the City of Refuge. 6 September 1933.

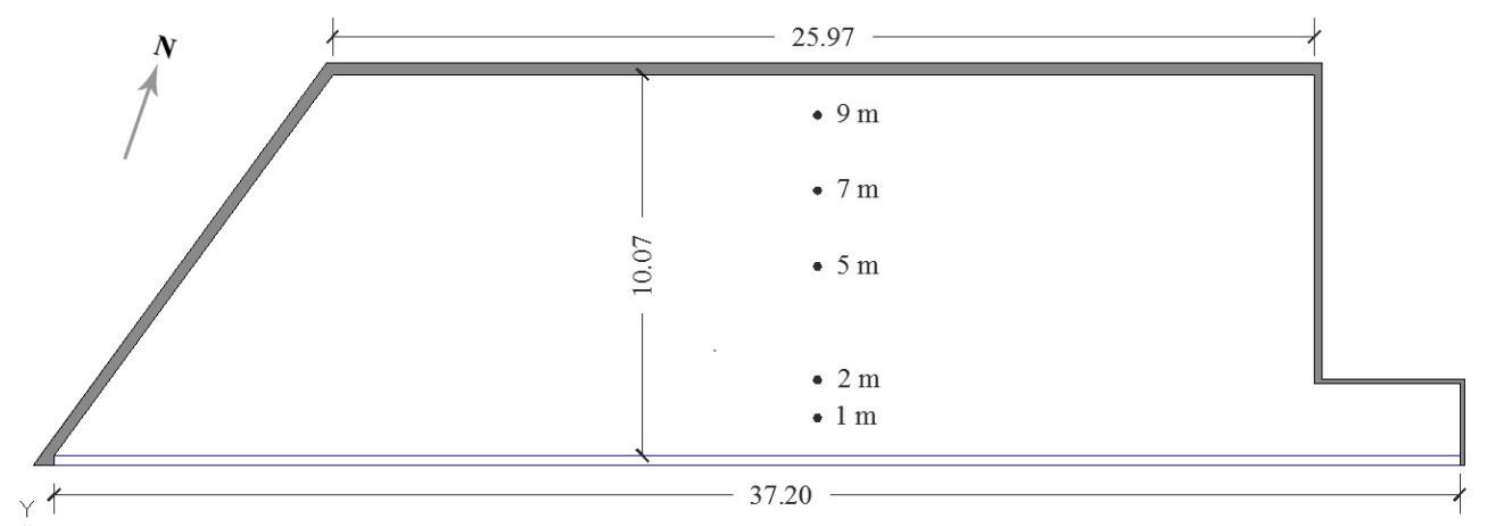

9a. Dimensions and points of measurement in the room in the City of Refuge.

\footnotetext{
${ }^{18}$ Fundation Le Corbusier. CR 3144. FLC 30842. CFLC-ADAGP
} 


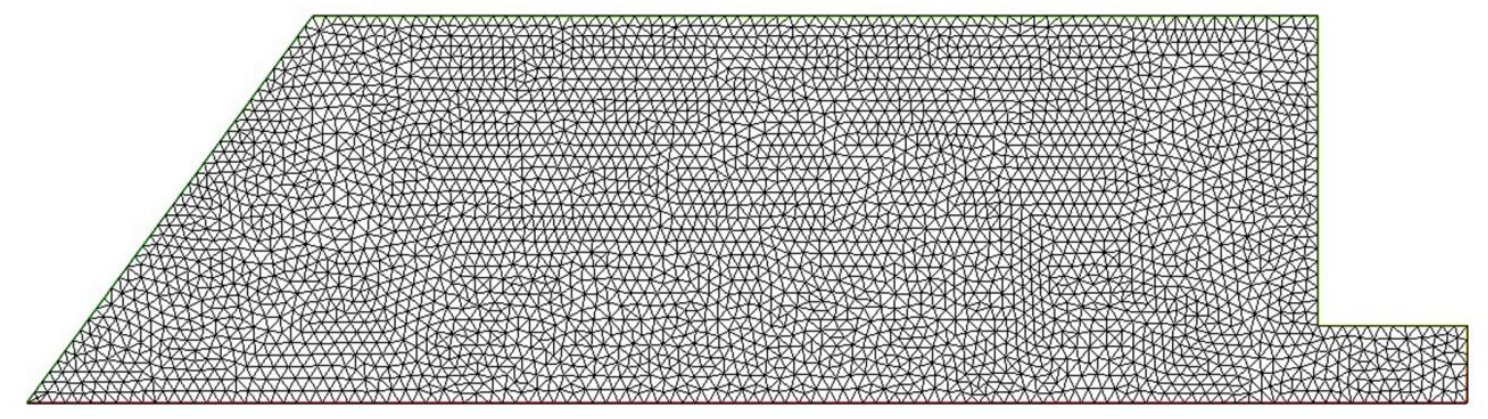

9b. CFD mesh density in the room in the City of Refuge.

9. CFD Model.

\subsection{CFD simulations in the City of Refuge model in winter with absence and presence of solar radiation}

Simulations were carried out on the CR model from the 27 to 31 December, but the only results specified here are those of the third and coldest day, 30 December, with an outdoor temperature ranging from $-6{ }^{\circ} \mathrm{C}$ at 8:00 $\mathrm{h}$ to $1{ }^{\circ} \mathrm{C}$ at $15: 00 \mathrm{~h}$ (table 8), once the operating conditions of the thermal system were stabilised. Both the presence and absence of solar radiation -not included by Saint Gobain in the tests- were simulated, in order to assess solar incidence on the evolution of indoor temperatures. The airflow used in the cavity was $100 \mathrm{l} / \mathrm{s}$ per metre along the mur neutralisant, as recommended by Saint Gobain engineers following the tests. The heat coefficient value $(\mathrm{Q})$ used was the same as that calculated by Saint Gobain engineers for this configuration of mur neutralisant and airflows. The following formula, proposed by Lyon, and based on outdoor temperature was used to calculate airflow temperature:

$$
\theta_{E}=21.6-\frac{T f}{5}
$$

where $\theta_{\mathrm{E}}$ equals airflow temperature and $\mathrm{T}_{\mathrm{f}}$ the outdoor temperature, both in ${ }^{\circ} \mathrm{C}$.

However, unlike constant airflow temperature criteria followed in the Saint Gobain tests, a simplification which could be considered as valid given the test duration, our simulations have considered a variable airflow temperature based on outdoor temperature, with no variation given the limited thermal inertia of the mur neutralisant. These calculations were spread out over four days, with day-night thermal oscillations, and a maximum value of $7{ }^{\circ} \mathrm{C}$ was reached on the third day (30 December). Therefore, applying Lyon's formula to each hour of these days, the airflow temperature varies depending on the outdoor temperature.

\subsubsection{Simulation with solar radiation}

Table 8 shows the results for simulations with solar radiation. The fifth and sixth columns show the respective surface temperatures of the outer and inner glazing of the mur neutralisant. The fourth column of the table gives the variable hot airflow temperature in the active chamber, values oscillating from $22.8{ }^{\circ} \mathrm{C}$ at $8: 00 \mathrm{~h}$ to $21.4{ }^{\circ} \mathrm{C}$ at 15:00h. These are relatively low values given the outdoor temperatures and the relatively low airflow, $100 \mathrm{l} / \mathrm{s} \mathrm{per}$ metre along the mur neutralisant, and provide an idea of the efficiency of the thermal system. 
Figures 10 and 11 show the results in a horizontal section at 8:00 h and 15:00 h, when the respective minimum and maximum outdoor temperatures are reached. In addition, figure 12 includes a series of graphs of the evolution of the temperature inside the room on the third day at hourly intervals depending on the distance from the mur neutralisant as well as its relationship to the outdoor temperature.

As can be seen, the maximum indoor temperatures are reached at 15:00 $\mathrm{h}$ and the minimum ones at 7:00 $\mathrm{h}$. The temperatures reached at the same distance from the mur neutralisant are fairly uniform throughout the day, with temperature differences between the two test hours of $1.14{ }^{\circ} \mathrm{C}$ at $1 \mathrm{~m}, 0.95{ }^{\circ} \mathrm{C}$ at $2 \mathrm{~m}, 0.49^{\circ} \mathrm{C}$ at $5 \mathrm{~m}, 0.26{ }^{\circ} \mathrm{C}$ at 7 $\mathrm{m}$ and $0.09^{\circ} \mathrm{C}$ at $9 \mathrm{~m}$. This uniformity of temperature therefore increases throughout the day with the distance from the mur neutralisant. The thermal uniformity on the outdoor glazing of the mur neutralisant is also significant. Although outdoor temperature varied by $7{ }^{\circ} \mathrm{C}$ on that day, the superficial temperature of the outdoor glazing only varied by $2.58^{\circ} \mathrm{C}$.

As was to be expected, there is less thermal uniformity in the room, although all its points fall within the temperature comfort band during the day, with a maximum temperature value of $23.73{ }^{\circ} \mathrm{C}$, at $1 \mathrm{~m}$ from the $\mathrm{mur}$ at 15:00 h, and a minimum value of $18.49^{\circ} \mathrm{C}$, at $9 \mathrm{~m}$ from the $m u r$ from 7:00 to 9:00 $\mathrm{h}$. At 15:00 h the difference in temperatures $1 \mathrm{~m}$ from the wall and $9 \mathrm{~m}$ from the wall (end locations in the room) is $5.15^{\circ} \mathrm{C}$, and at 7:00 h it is $4.10^{\circ} \mathrm{C}$. The difference in the half of the room closest to the mur neutralisant is more pronounced, as the differences in temperature $5 \mathrm{~m}$ from the mur neutralisant and $9 \mathrm{~m}$. from the mur neutralisant are $2.41{ }^{\circ} \mathrm{C}$ at 15:00 $\mathrm{h}$ and 2.01 at 7:00 $\mathrm{h}$.

As stated by our research group in the CFD simulations using a numerical model of the combined effect of the mur neutralisant and respiration exacte, the function of respiration exacte is not merely limited to improving indoor air quality but also contributes to greater thermal uniformity in the room, thus improving the comfort conditions of the thermal system ${ }^{19}$.

\footnotetext{
${ }^{19}$ Ramírez Balas, C.; Fernández Nieto, E.D.; Narbona Reina,G.; Sendra, J. J.; Suárez, R. "Numerical simulation of the temperature evolution in a room with a mur neutralisant. Application to 'The City of Refuge' by Le Corbusier". Energy and buildings. 2015. 86. pp. 708-722.
} 


\begin{tabular}{|c|c|c|c|c|c|c|c|c|c|c|}
\hline 30-Dec & $\begin{array}{c}\text { Io } \\
\mathrm{W} / \mathrm{m}^{2}\end{array}$ & $\begin{array}{c}\text { Text } \\
{ }^{\circ} \mathrm{C}\end{array}$ & $\begin{array}{c}\text { Timp } \\
{ }^{\circ} \mathrm{C}\end{array}$ & $\begin{array}{c}\text { Teg } \\
{ }^{\circ} \mathrm{C}\end{array}$ & $\begin{array}{l}\mathrm{Tig} \\
{ }^{\circ} \mathrm{C}\end{array}$ & $\begin{array}{c}\mathrm{T}(1 \mathrm{~m}) \\
{ }^{\circ} \mathrm{C}\end{array}$ & $\begin{array}{c}\mathrm{T}(2 \mathrm{~m}) \\
{ }^{\circ} \mathrm{C}\end{array}$ & $\begin{array}{c}\mathrm{T}(5 \mathrm{~m}) \\
{ }^{\circ} \mathrm{C}\end{array}$ & $\begin{array}{c}\mathrm{T}(7 \mathrm{~m}) \\
{ }^{\circ} \mathrm{C}\end{array}$ & $\begin{array}{c}\mathrm{T}(9 \mathrm{~m}) \\
{ }^{\circ} \mathrm{C}\end{array}$ \\
\hline 1:00 & 229 & -3.8 & 22.36 & 11.92 & 22.53 & 22.68 & 22.16 & 20.58 & 19.54 & 18.51 \\
\hline 2:00 & 228 & -4 & 22.4 & 11.78 & 22.5 & 22.66 & 22.13 & 20.56 & 19.53 & 18.51 \\
\hline $3: 00$ & 232 & -3 & 22.2 & 11.73 & 22.47 & 22.62 & 22.11 & 20.55 & 19.52 & 18.51 \\
\hline 4:00 & 227 & -4.2 & 22.44 & 11.61 & 22.45 & 22.61 & 22.09 & 20.53 & 19.51 & 18.50 \\
\hline 5:00 & 228 & -4 & 22.4 & 11.53 & 22.44 & 22.59 & 22.07 & 20.52 & 19.50 & 18.50 \\
\hline $6: 00$ & 224 & -5 & 22.6 & 11.39 & 22.44 & 22.59 & 22.07 & 20.51 & 19.49 & 18.50 \\
\hline 7:00 & 225 & -4.8 & 22.56 & 11.29 & 22.44 & 22.59 & 22.07 & 20.50 & 19.49 & 18.49 \\
\hline 8:00 & 221 & -6 & 22.8 & 11.13 & 22.47 & 22.61 & 22.08 & 20.50 & 19.49 & 18.49 \\
\hline 9:00 & 226 & -5 & 22.6 & 11.11 & 22.49 & 22.63 & 22.09 & 20.51 & 19.49 & 18.49 \\
\hline $10: 00$ & 287 & -4.3 & 22.46 & 11.31 & 22.64 & 22.71 & 22.14 & 20.52 & 19.50 & 18.50 \\
\hline 11:00 & 628 & -4 & 22.4 & 11.72 & 22.95 & 22.92 & 22.28 & 20.56 & 19.51 & 18.50 \\
\hline $12: 00$ & 865 & -2 & 22 & 12.34 & 23.30 & 23.20 & 22.50 & 20.64 & 19.55 & 18.51 \\
\hline 13:00 & 1017 & -0.1 & 21.62 & 12.98 & 23.59 & 23.46 & 22.72 & 20.76 & 19.61 & 18.53 \\
\hline 14:00 & 932 & 0 & 21.6 & 13.44 & 23.78 & 23.65 & 22.91 & 20.89 & 19.68 & 18.55 \\
\hline $15: 00$ & 861 & 1 & 21.4 & 13.69 & 23.78 & 23.73 & 23.02 & 20.99 & 19.75 & 18.58 \\
\hline 16:00 & 531 & 0 & 21.6 & 13.60 & 23.62 & 23.66 & 23.01 & 21.05 & 19.80 & 18.59 \\
\hline $17: 00$ & 279 & -1 & 21.8 & 13.34 & 23.41 & 23.51 & 22.92 & 21.06 & 19.82 & 18.60 \\
\hline $18: 00$ & 237 & -2 & 22 & 13.05 & 23.23 & 23.37 & 22.80 & 21.02 & 19.81 & 18.60 \\
\hline $19: 00$ & 236 & -2.3 & 22.06 & 12.80 & 23.09 & 23.24 & 22.69 & 20.96 & 19.78 & 18.59 \\
\hline 20:00 & 240 & -3 & 22.2 & 12.56 & 22.98 & 23.14 & 22.59 & 20.89 & 19.74 & 18.58 \\
\hline 21:00 & 244 & -4 & 22.4 & 12.30 & 22.91 & 23.07 & 22.52 & 20.84 & 19.70 & 18.57 \\
\hline $22: 00$ & 250 & -3.6 & 22.32 & 12.13 & 22.84 & 23.00 & 22.46 & 20.79 & 19.67 & 18.56 \\
\hline 23:00 & 257 & -3 & 22.2 & 12.04 & 22.78 & 22.94 & 22.40 & 20.75 & 19.65 & 18.55 \\
\hline $24: 00$ & 261 & -2 & 22 & 12.05 & 22.71 & 22.87 & 22.34 & 20.71 & 19.63 & 18.54 \\
\hline
\end{tabular}

Table 8. Results of the temperatures for the mur neutralisant and different points of the room on 30 December, with solar radiation.

IsoValue

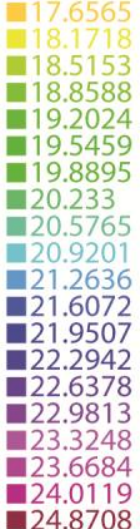

10. Results of the CFD simulation (horizontal section of the model) with air heating and solar radiation: 30 December, 8:00 h. 


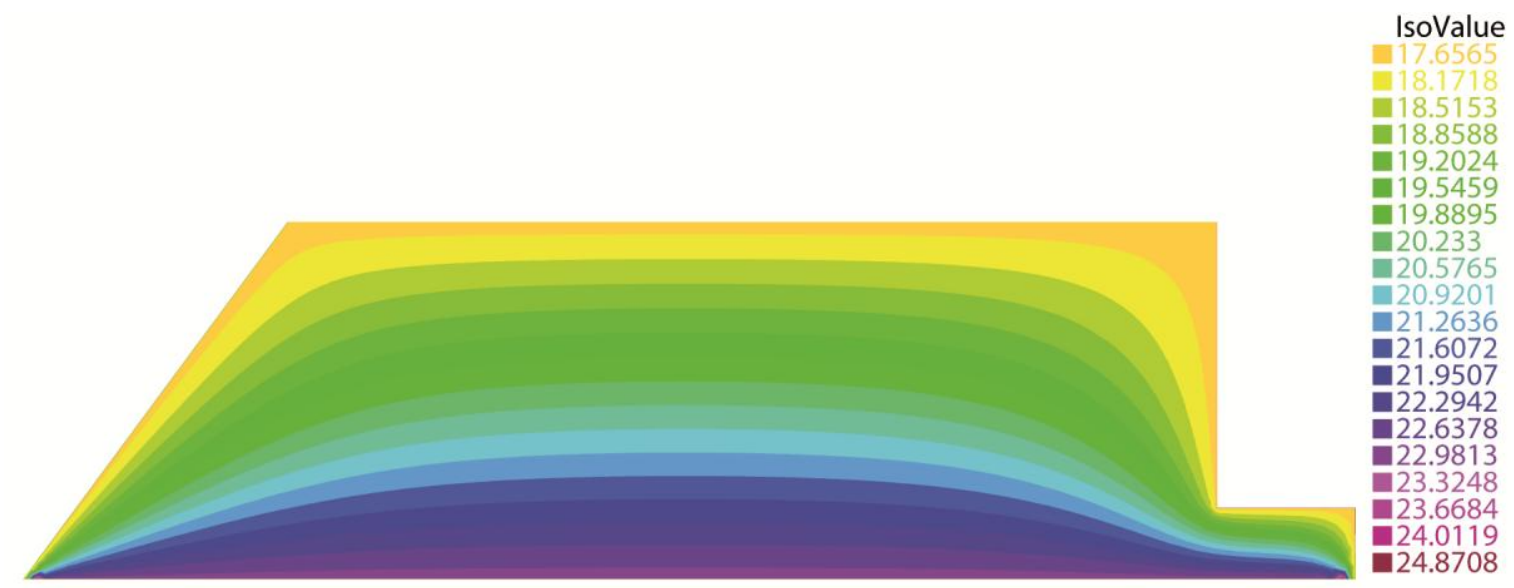

11. Results of the CFD simulation (horizontal section of the model) with air heating and solar radiation: 30 December, 15:00 h.

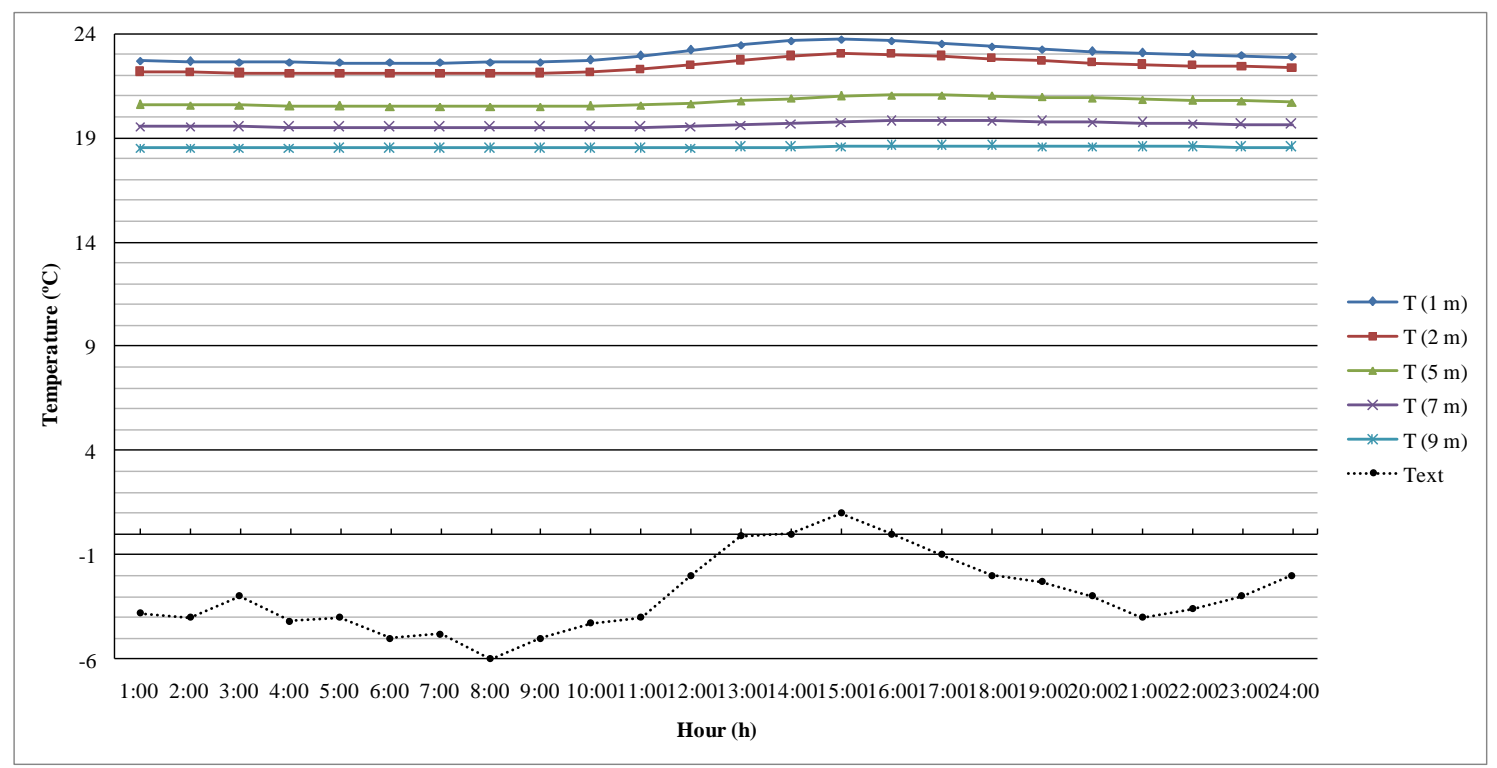

12. Evolution of indoor temperature at different points in the room for 30 December, with solar radiation, with airflow $q=100$ $1 / \mathrm{s}$ and a variable airflow temperature in the active chamber.

\subsubsection{Simulation without solar radiation}

Table 9 and figures 13, 14 and 15 show the same results in the absence of solar radiation, confirming the influence of solar radiation on the operation of the system. Without radiation uniformity throughout the day was very pronounced. In figure 15 the graphs showing the evolution of indoor temperatures at different distances from the mur neutralisant are almost straight lines. The maximum difference is $0.12{ }^{\circ} \mathrm{C}$ at $1 \mathrm{~m}$ from the mur compared with $1.14{ }^{\circ} \mathrm{C}$ occurring with solar radiation. Uniformity in the surface temperature of the outer glazing is also more pronounced: there is a maximum oscillation of only $0.99{ }^{\circ} \mathrm{C}$ in the exterior surface temperature compared with the $7^{\circ} \mathrm{C}$ variation in outdoor temperature.

Equally, thermal uniformity in the room is more pronounced without solar radiation. The maximum indoor temperature is $21.18^{\circ} \mathrm{C}$ at $15: 00 \mathrm{~h}$ and $1 \mathrm{~m}$ from the mur neutralisant, and the minimum is $18.32{ }^{\circ} \mathrm{C}$ at $1: 00 \mathrm{~h}$ and $9 \mathrm{~m}$ from the mur neutralisant. There is therefore a difference of only $2.86{ }^{\circ} \mathrm{C}$ for these positions and 
extreme hours. At 15:00 h, the difference between indoor temperature at $1 \mathrm{~m}$ and $9 \mathrm{~m}$ from the mur neutralisant is $2.82{ }^{\circ} \mathrm{C}$, compared with a difference of $5.15^{\circ} \mathrm{C}$ occurring with solar radiation.

As regards the temperature values reached in both hypotheses it can be observed that at 15:00 $\mathrm{h}$ (day), this difference is $2.65{ }^{\circ} \mathrm{C}$ at $1 \mathrm{~m}, 2.18^{\circ} \mathrm{C}$ at $2 \mathrm{~m}, 1.20^{\circ} \mathrm{C}$ at $5 \mathrm{~m}, 0.68^{\circ} \mathrm{C}$ at $5 \mathrm{~m}$ and $0.18{ }^{\circ} \mathrm{C}$ at $9 \mathrm{~m}$, while at $1: 00 \mathrm{~h}$ (night) the difference is $1.33^{\circ} \mathrm{C}$ at $1 \mathrm{~m}, 1.20^{\circ} \mathrm{C}$ at $2 \mathrm{~m}, 0.77^{\circ} \mathrm{C}$ at $5 \mathrm{~m}, 0.46^{\circ} \mathrm{C}$ at $5 \mathrm{~m}$ and $0.16^{\circ} \mathrm{C}$ at $9 \mathrm{~m}$.

It should be noted that based on the solar radiation values extracted from the climate table, 30 December was a fairly sunny day. On an overcast day, the worst case scenario for winter, the results for both hypotheses simulated would be quite similar.

\begin{tabular}{|c|c|c|c|c|c|c|c|c|c|c|}
\hline 30-Dec & $\begin{array}{c}\text { Io } \\
\mathrm{W} / \mathrm{m}^{2}\end{array}$ & $\begin{array}{c}\text { Text } \\
{ }^{\circ} \mathrm{C}\end{array}$ & $\begin{array}{l}\text { Timp } \\
{ }^{\circ} \mathrm{C}\end{array}$ & $\begin{array}{l}\text { Teg } \\
{ }^{\circ} \mathrm{C}\end{array}$ & $\begin{array}{l}\text { Tig } \\
{ }^{\circ} \mathrm{C}\end{array}$ & $\begin{array}{c}\mathrm{T}(1 \mathrm{~m}) \\
{ }^{\circ} \mathrm{C}\end{array}$ & $\begin{array}{c}\mathrm{T}(2 \mathrm{~m}) \\
{ }^{\circ} \mathrm{C}\end{array}$ & $\begin{array}{c}\mathrm{T}(5 \mathrm{~m}) \\
{ }^{\circ} \mathrm{C}\end{array}$ & $\begin{array}{c}\mathrm{T}(7 \mathrm{~m}) \\
{ }^{\circ} \mathrm{C}\end{array}$ & $\begin{array}{c}\mathrm{T}(9 \mathrm{~m}) \\
{ }^{\circ} \mathrm{C}\end{array}$ \\
\hline $1: 00$ & 0 & -3.8 & 22.36 & 10.82 & 21.52 & 21.10 & 20.72 & 19.65 & 18.98 & 18.32 \\
\hline 2:00 & 0 & -4 & 22.4 & 10.73 & 21.33 & 21.14 & 20.76 & 19.67 & 18.99 & 18.33 \\
\hline $3: 00$ & 0 & -3 & 22.2 & 10.70 & 21.54 & 21.16 & 20.78 & 19.69 & 19.00 & 18.33 \\
\hline $4: 00$ & 0 & -4.2 & 22.44 & 10.62 & 21.51 & 21.19 & 20.81 & 19.71 & 19.01 & 18.34 \\
\hline $5: 00$ & 0 & -4 & 22.4 & 10.54 & 21.69 & 21.22 & 20.84 & 19.73 & 19.02 & 18.34 \\
\hline $6: 00$ & 0 & -5 & 22.6 & 10.43 & 21.64 & 21.26 & 20.87 & 19.74 & 19.03 & 18.34 \\
\hline $7: 00$ & 0 & -4.8 & 22.56 & 10.34 & 21.85 & 21.30 & 20.90 & 19.76 & 19.04 & 18.35 \\
\hline 8:00 & 0 & -6 & 22.8 & 10.20 & 21.66 & 21.34 & 20.94 & 19.78 & 19.05 & 18.35 \\
\hline 9:00 & 0 & -5 & 22.6 & 10.17 & 21.53 & 21.38 & 20.97 & 19.81 & 19.07 & 18.35 \\
\hline $10: 00$ & 0 & -4.3 & 22.46 & 10.19 & 21.47 & 21.39 & 20.99 & 19.82 & 19.08 & 18.36 \\
\hline 11:00 & 0 & -4 & 22.4 & 10.24 & 21.21 & 21.40 & 21.00 & 19.84 & 19.09 & 18.36 \\
\hline $12: 00$ & 0 & -2 & 22 & 10.42 & 21.17 & 21.38 & 20.99 & 19.84 & 19.09 & 18.36 \\
\hline $13: 00$ & 0 & -0.1 & 21.62 & 10.69 & 21.10 & 21.32 & 20.95 & 19.84 & 19.09 & 18.36 \\
\hline $14: 00$ & 0 & 0 & 21.6 & 10.92 & 21.04 & 21.25 & 20.90 & 19.81 & 19.09 & 18.36 \\
\hline $15: 00$ & 0 & 1 & 21.4 & 11.16 & 20.97 & 21.18 & 20.84 & 19.79 & 19.07 & 18.36 \\
\hline $16: 00$ & 0 & 0 & 21.6 & 11.28 & 21.00 & 21.13 & 20.79 & 19.75 & 19.05 & 18.35 \\
\hline 17:00 & 0 & -1 & 21.8 & 11.29 & 21.19 & 21.09 & 20.76 & 19.72 & 19.03 & 18.34 \\
\hline 18:00 & 0 & -2 & 22 & 11.23 & 21.24 & 21.09 & 20.74 & 19.70 & 19.02 & 18.34 \\
\hline 19:00 & 0 & -2.3 & 22.06 & 11.16 & 21.36 & 21.09 & 20.74 & 19.69 & 19.01 & 18.34 \\
\hline 20:00 & 0 & -3 & 22.2 & 11.05 & 21.54 & 21.11 & 20.75 & 19.69 & 19.01 & 18.33 \\
\hline 21:00 & 0 & -4 & 22.4 & 10.90 & 21.45 & 21.14 & 20.77 & 19.69 & 19.01 & 18.33 \\
\hline $22: 00$ & 0 & -3.6 & 22.32 & 10.82 & 21.34 & 21.17 & 20.79 & 19.70 & 19.01 & 18.33 \\
\hline 23:00 & 0 & -3 & 22.2 & 10.81 & 21.15 & 21.18 & 20.81 & 19.72 & 19.02 & 18.34 \\
\hline 24:00 & 0 & -2 & 22 & 10.86 & 21.12 & 21.18 & 20.81 & 19.72 & 19.02 & 18.34 \\
\hline
\end{tabular}

Table 9. Results of the temperatures of the mur neutralisant and the room at the different points measured for 30 December, without solar radiation. 
IsoValue

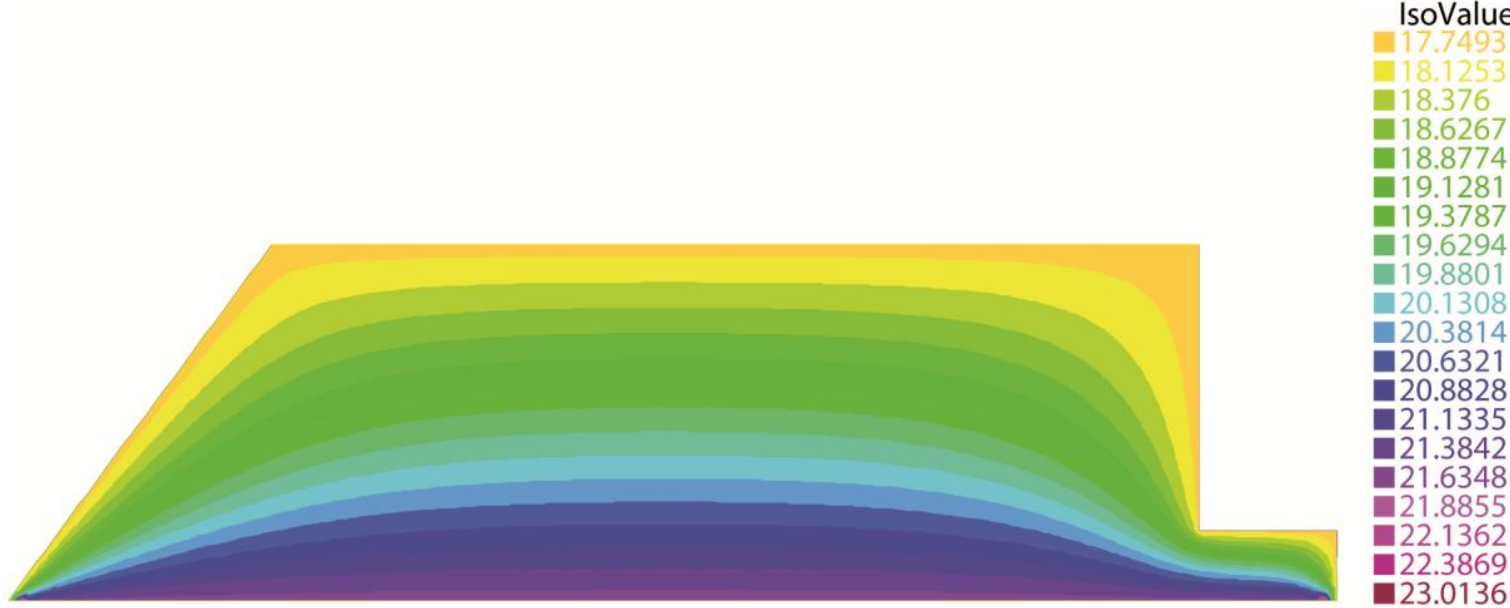

13. Results of the CFD simulation (horizontal section of the model) with air heating and no solar radiation: 30 December, 8:00 h.

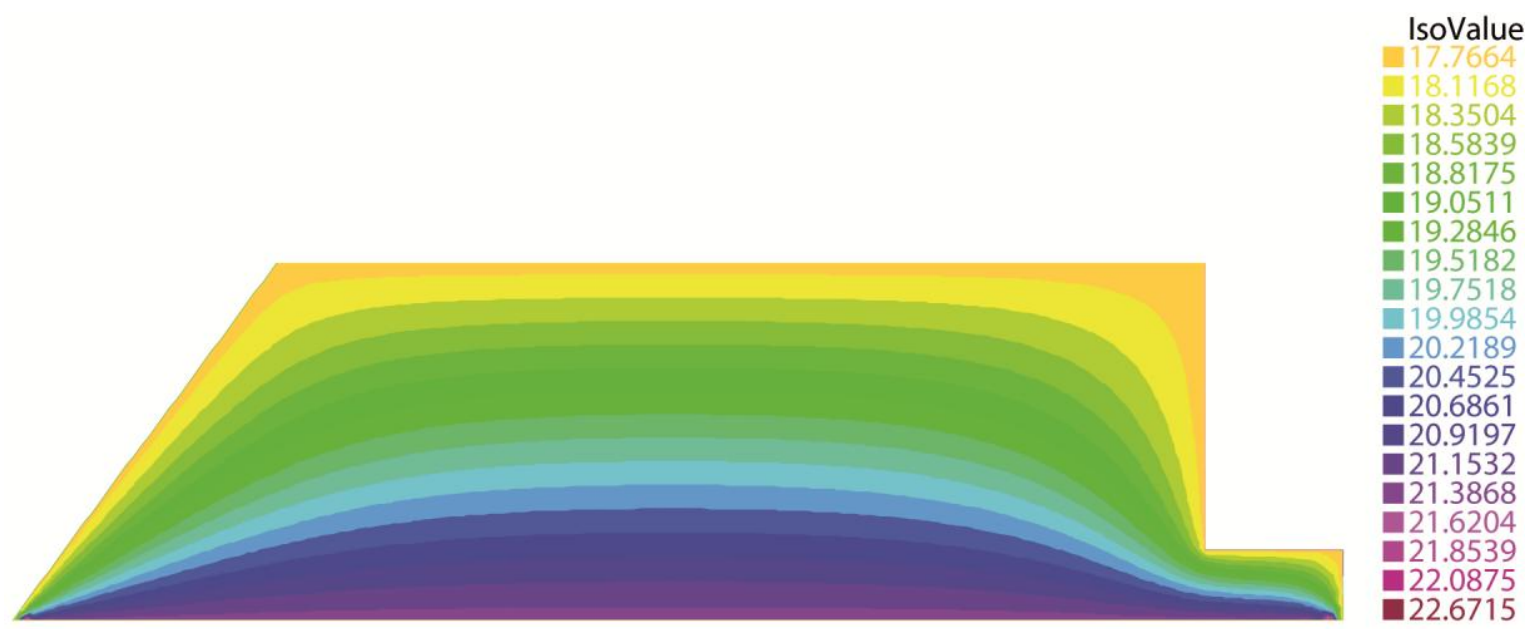

14. Results of the CFD simulation (horizontal section of the model) with air heating and no solar radiation: 30 December, 15:00 h. 


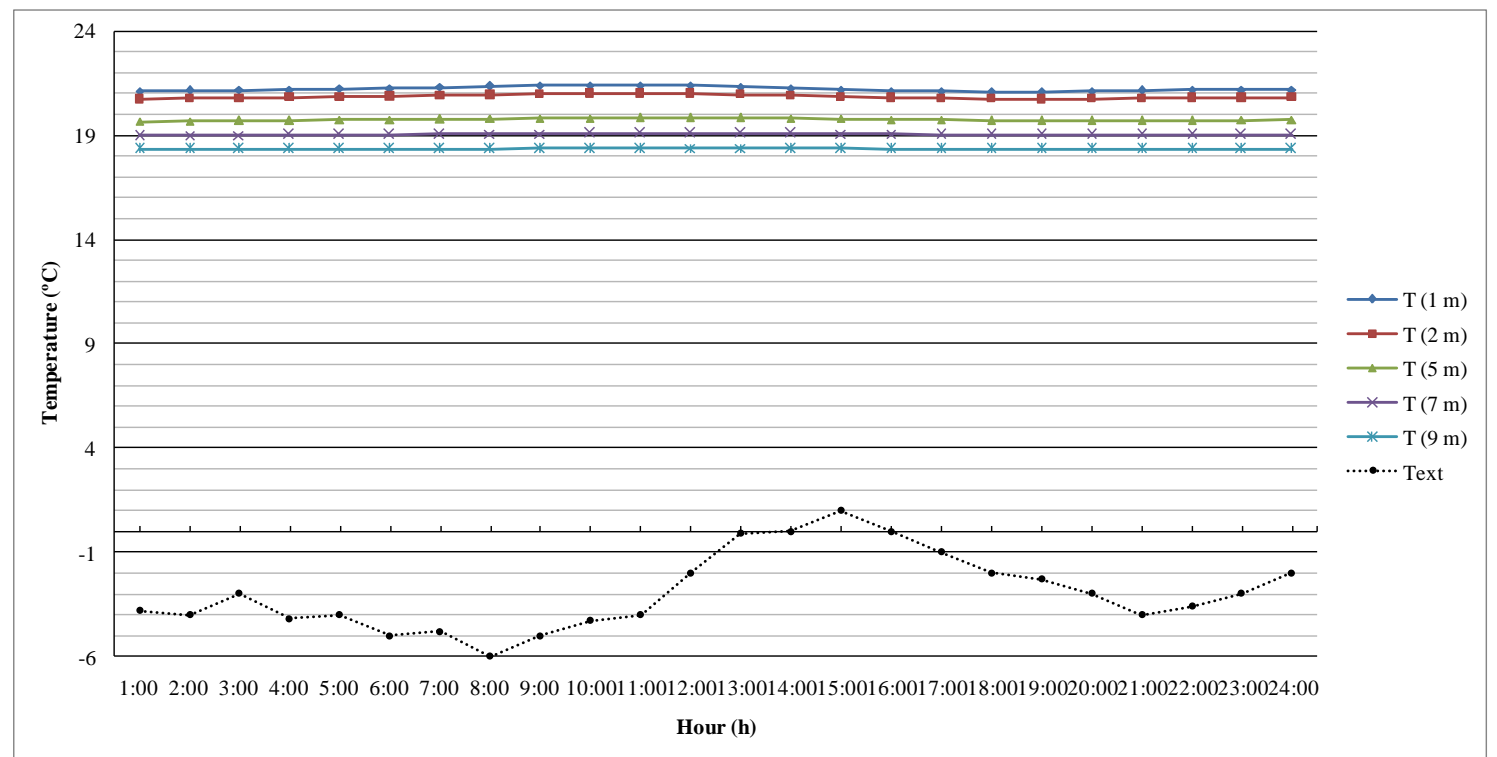

15. Evolution of indoor temperature at different points in the room on 30 December, without solar radiation, with airflow $\mathrm{q}=100 \mathrm{l} / \mathrm{s}$ and variable airflow temperature in the active chamber.

\subsection{CFD simulations of the City of Refuge model in the summer}

Simulations were carried out on the CR model from 29 June to 3 July, but as in the case of winter, only the results for the third and hottest day, 2 July, were specified once the operating conditions of the thermal system were stabilised. In this case only solar radiation was simulated. The airflow selected in the air cavity was also 100 1/s per metre along the mur neutralisant. Lyon's formula was also used to calculate the airflow temperature, which was still considered variable depending on outdoor temperature.

Table 10 shows the results for the simulations with solar radiation. The respective surface temperatures of the outer and inner glazing of the mur neutralisant are shown in the fifth and sixth columns. The fourth column of the table shows the variable hot airflow temperature in the active chamber, with values ranging from $18.2^{\circ} \mathrm{C}$ at 6:00 $\mathrm{h}$ to $15.6^{\circ} \mathrm{C}$ at 14:00-15:00 $\mathrm{h}$. These are quite high values given the outdoor temperatures and relatively low airflow, 100 l/s per metre along the mur neutralisant, and provide an idea of the efficiency of the thermal system.

Figure 16 shows the results in a horizontal section at 15:00 h, when the maximum exterior temperature is reached. In addition, figure 17 includes a series of graphs showing the evolution of the temperature inside the room on the third day at hourly intervals, depending on the distance from the mur neutralisant and its relationship with the outdoor temperature.

As can be observed the maximum indoor temperatures are reached between 15:00 and 18:00 $\mathrm{h}$ and the minimum temperatures between 6:00 and 8:00 h. Relatively uniform temperatures are obtained throughout the day at the same distance from the mur neutralisant, although logically this homogeneity is less pronounced than in winter given the greater incidence of solar radiation and the greater variability in outdoor temperatures, with differences at these extreme times of $3.39{ }^{\circ} \mathrm{C}$ at $1 \mathrm{~m}, 2.92{ }^{\circ} \mathrm{C}$ at $2 \mathrm{~m}, 1.73{ }^{\circ} \mathrm{C}$ at $5 \mathrm{~m}, 1.01{ }^{\circ} \mathrm{C}$ at $7 \mathrm{~m}$ and $0.34{ }^{\circ} \mathrm{C}$ at $9 \mathrm{~m}$. Therefore, as in winter, the uniformity of these temperatures increases throughout the day along with the distance from the mur neutralisant. The thermal uniformity on the outer glazing of the mur neutralisant is also significant. Although outdoor temperature varies by $13{ }^{\circ} \mathrm{C}$ on 2 July, the surface temperature of the outer glazing only varies by $6.33^{\circ} \mathrm{C}$, slightly less than half the previous value. 
Although there was less thermal uniformity in the room throughout the day, all points in the room were within the comfort band, with a maximum temperature value of $23.80^{\circ} \mathrm{C}, 1 \mathrm{~m}$ from the mur neutralisant at 15:00 h, and a minimum value of $18.27^{\circ} \mathrm{C} 9 \mathrm{~m}$ from the mur neutralisant and from 7:00 to 8:00 $\mathrm{h}$, values very similar to those obtained in winter at the same points in the room and at the same time. This shows the potential of the thermal system to maintain similar environmental conditions inside, regardless of the outdoor temperature. At 15:00 $\mathrm{h}$ the difference in temperatures $1 \mathrm{~m}$ from the mur and $9 \mathrm{~m}$ from the mur (extreme locations in the room) was $5.25^{\circ} \mathrm{C}$, and at $6: 00 \mathrm{~h}$ it was $2.13^{\circ} \mathrm{C}$. This difference is more pronounced in the half of the room closest to the mur neutralisant, as the differences in temperature $5 \mathrm{~m}$ from the mur neutralisant and $9 \mathrm{~m}$. from the mur were $2.38^{\circ} \mathrm{C}$ at $15: 00 \mathrm{~h}$ and $1.10^{\circ} \mathrm{C}$ at $6: 00 \mathrm{~h}$.

As was already stated in the discussion of results for winter with solar radiation, respiration exacte contributes to greater thermal uniformity in the room, thus improving the comfort conditions of the thermal system.

\begin{tabular}{|c|c|c|c|c|c|c|c|c|c|c|}
\hline 02-Jul & $\begin{array}{c}\text { Io } \\
\text { W/m² }\end{array}$ & $\begin{array}{l}\text { Text } \\
{ }^{\circ} \mathrm{C}\end{array}$ & $\begin{array}{l}\text { Timp } \\
{ }^{\circ} \mathrm{C}\end{array}$ & $\begin{array}{l}\text { Teg } \\
{ }^{\circ} \mathrm{C}\end{array}$ & $\begin{array}{l}\text { Tig } \\
{ }^{\circ} \mathrm{C}\end{array}$ & $\begin{array}{c}\mathrm{T}(1 \mathrm{~m}) \\
{ }^{\circ} \mathrm{C}\end{array}$ & $\begin{array}{c}\mathrm{T}(2 \mathrm{~m}) \\
{ }^{\circ} \mathrm{C}\end{array}$ & $\begin{array}{c}\mathrm{T}(5 \mathrm{~m}) \\
{ }^{\circ} \mathrm{C}\end{array}$ & $\begin{array}{c}\mathrm{T}(7 \mathrm{~m}) \\
{ }^{\circ} \mathrm{C}\end{array}$ & $\begin{array}{c}\mathrm{T}(9 \mathrm{~m}) \\
{ }^{\circ} \mathrm{C}\end{array}$ \\
\hline $1: 00$ & 344 & 19.9 & 17.62 & 22.13 & 21.16 & 21.103 & 20.874 & 19.967 & 19.222 & 18.414 \\
\hline $2: 00$ & 339 & 19 & 17.8 & 21.64 & 20.97 & 20.89 & 20.664 & 19.806 & 19.119 & 18.379 \\
\hline $3: 00$ & 339 & 19 & 17.8 & 20.83 & 20.66 & 20.706 & 20.486 & 19.67 & 19.031 & 18.349 \\
\hline $4: 00$ & 335 & 18.2 & 17.96 & 20.57 & 20.57 & 20.555 & 20.336 & 19.556 & 18.957 & 18.323 \\
\hline $5: 00$ & 334 & 18 & 18 & 20.22 & 20.48 & 20.434 & 20.215 & 19.46 & 18.895 & 18.301 \\
\hline $6: 00$ & 369 & 17 & 18.2 & 20.2 & 20.5 & 20.415 & 20.158 & 19.386 & 18.844 & 18.284 \\
\hline $7: 00$ & 715 & 18.7 & 17.86 & 20.54 & 20.72 & 20.559 & 20.227 & 19.359 & 18.814 & 18.272 \\
\hline $8: 00$ & 1127 & 20 & 17.6 & 21.12 & 21.12 & 20.881 & 20.442 & 19.4 & 18.819 & 18.27 \\
\hline 9:00 & 1557 & 22 & 17.2 & 21.85 & 21.85 & 21.341 & 20.789 & 19.523 & 18.869 & 18.283 \\
\hline $10: 00$ & 1840 & 23.4 & 16.92 & 22.76 & 22.4 & 21.872 & 21.219 & 19.718 & 18.965 & 18.311 \\
\hline 11:00 & 2046 & 26 & 16.4 & 23.77 & 22.88 & 22.412 & 21.68 & 19.963 & 19.097 & 18.353 \\
\hline $12: 00$ & 2180 & 28 & 16 & 24.76 & 23.21 & 22.919 & 22.131 & 20.23 & 19.251 & 18.402 \\
\hline 13:00 & 2231 & 29.4 & 15.72 & 25.62 & 23.9 & 23.351 & 22.536 & 20.497 & 19.41 & 18.455 \\
\hline $14: 00$ & 2138 & 30 & 15.6 & 26.23 & 23.8 & 23.66 & 22.852 & 20.738 & 19.562 & 18.506 \\
\hline $15: 00$ & 1923 & 30 & 15.6 & 26.51 & 24.03 & 23.803 & 23.041 & 20.929 & 19.69 & 18.551 \\
\hline $16: 00$ & 1591 & 29.8 & 15.64 & 26.53 & 24.08 & 23.777 & 23.085 & 21.046 & 19.781 & 18.585 \\
\hline $17: 00$ & 1360 & 29 & 15.8 & 26.32 & 23.87 & 23.635 & 23.014 & 21.087 & 19.826 & 18.603 \\
\hline 18:00 & 1140 & 30 & 15.6 & 26.04 & 23.12 & 23.362 & 22.832 & 21.056 & 19.828 & 18.607 \\
\hline 19:00 & 855 & 29 & 15.8 & 25.57 & 22.84 & 22.976 & 22.542 & 20.955 & 19.788 & 18.597 \\
\hline 20:00 & 588 & 28 & 16 & 24.99 & 22.54 & 22.518 & 22.174 & 20.792 & 19.708 & 18.574 \\
\hline 21:00 & 411 & 26 & 16.4 & 24.32 & 22.09 & 22.064 & 21.782 & 20.583 & 19.596 & 18.539 \\
\hline 22:00 & 384 & 25.4 & 16.52 & 23.76 & 21.37 & 21.654 & 21.413 & 20.358 & 19.466 & 18.497 \\
\hline 23:00 & 380 & 24 & 16.8 & 23.21 & 21.01 & 21.307 & 21.087 & 20.139 & 19.334 & 18.453 \\
\hline $24: 00$ & 382 & 24 & 16.8 & 22.78 & 20.79 & 21.004 & 20.802 & 19.94 & 19.21 & 18.411 \\
\hline
\end{tabular}

Table 10. Results of the temperatures of the mur neutralisant and the room at the different points measured on 2 July. 


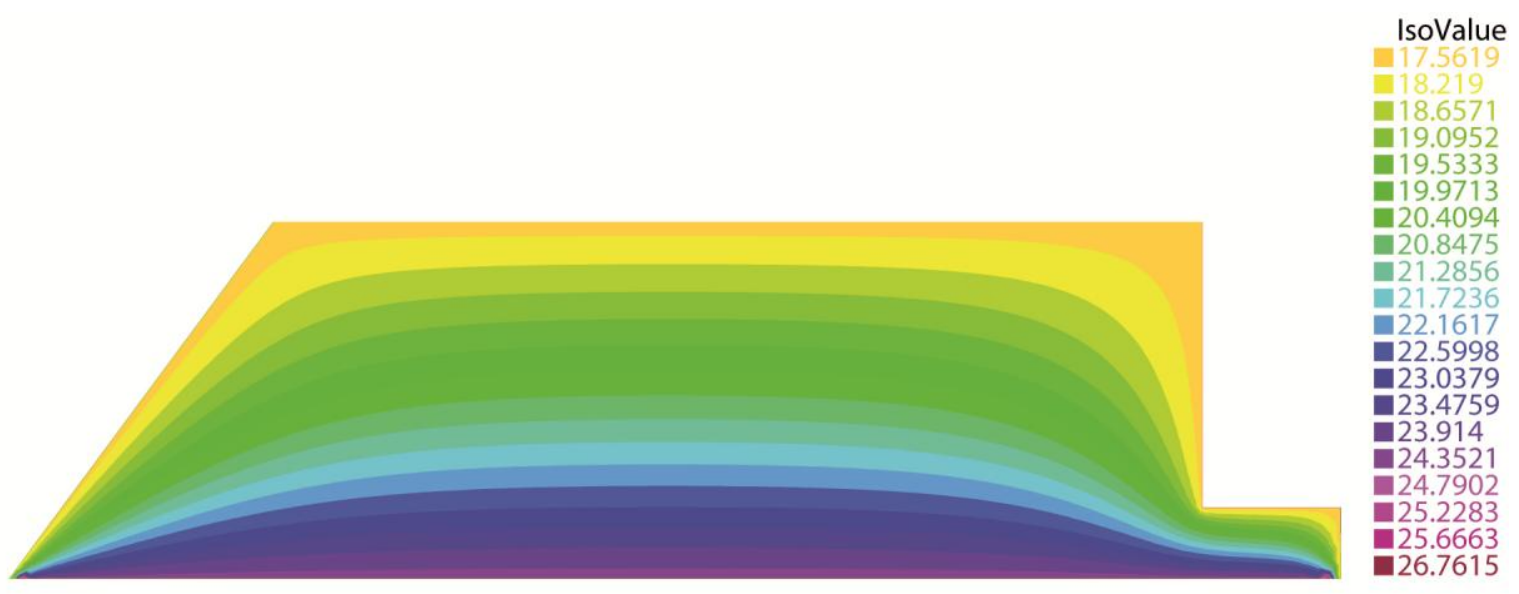

16. Results of the CFD simulation (horizontal section of the model) with air heating and solar radiation: 2 July, 15:00 $\mathrm{h}$.

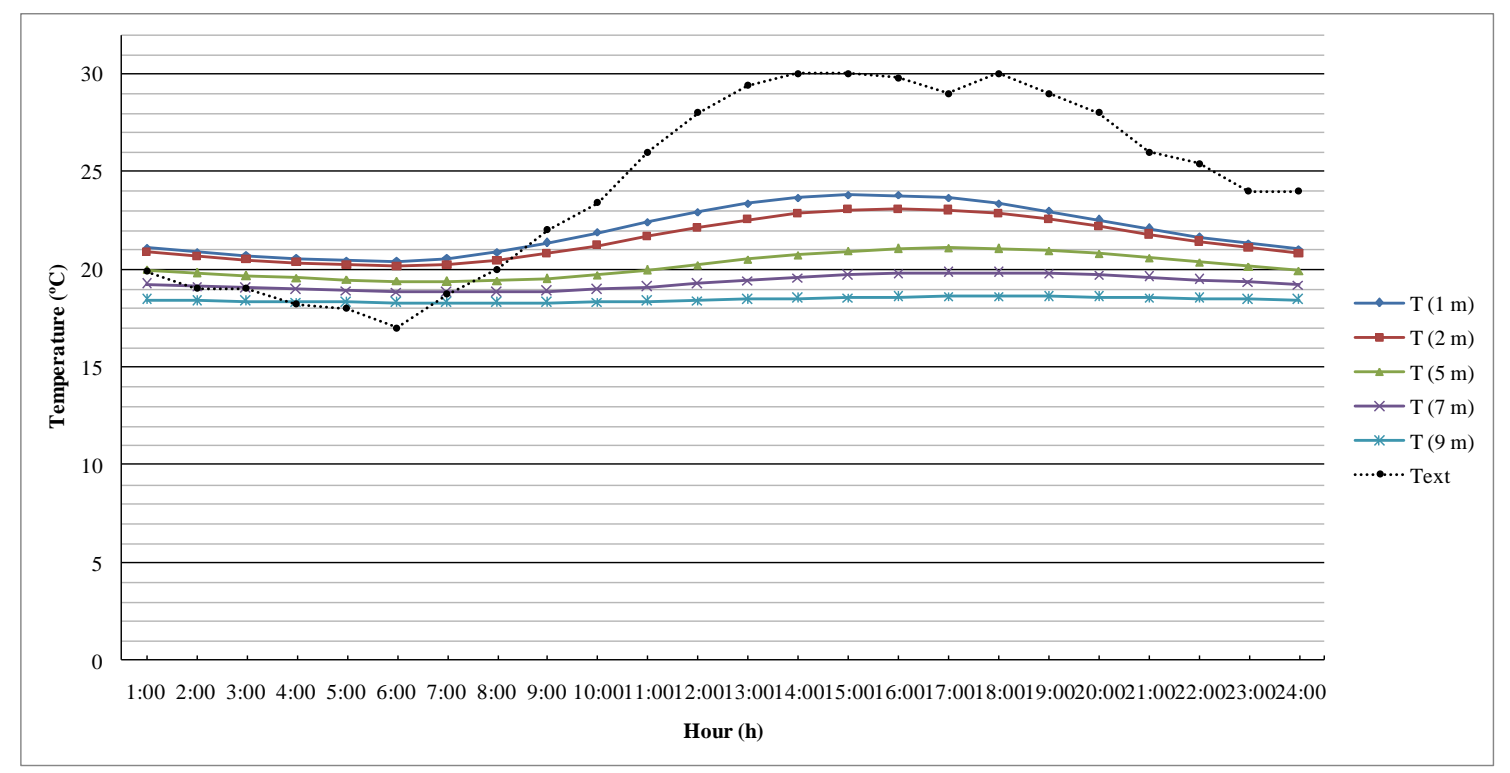

17. Evolution of the indoor temperature at different points in the room on 2 July, with solar radiation, with airflow q=100 1/s and variable airflow temperature of the active chamber.

\section{Conclusions}

The combined technological innovation of the mur neutralisant and respiration exacte proposed by Le Corbusier, with the help of G. Lyon, constituted a new interpretation of the mechanisation of the environment to solve the control of indoor climate in Modern Movement. Based on the data and conclusions of the mur neutralisant tests carried out by Saint Gobain engineers on physical models in test rooms in the 1930s, a numerical model was validated and implemented using the CFD-based program FreeFem++. This made it possible to observe the behaviour the mur neutralisant in the City of Refuge would have displayed under different environmental and operating conditions had the original design been completely carried out. 
The numerical model allows the energy simulation of the south-facing mur neutralisantof the main dormitory in the City of Refuge. The mur neutralisant is made up of two sheets of $7 \mathrm{~mm}$ glass with a $110 \mathrm{~mm}$ active air chamber, a hypothesis which is very similar to that proposed in the original project by Le Corbusier. Airflow in this mur was $100 \mathrm{l} / \mathrm{s}$ per metre along the mur neutralisant at a temperature which varied according to outdoor temperature. In winter conditions, represented by a sunny winter's day in Paris, with outdoor temperatures oscillating between and $-6^{\circ} \mathrm{C}$ and $1{ }^{\circ} \mathrm{C}$ on the same day, and with an airflow temperature in the chamber varying between $22.8^{\circ} \mathrm{C}$ and $21.4{ }^{\circ} \mathrm{C}$, notably uniform indoor temperatures occur in the room throughout the day at the same distance from the mur neutralisant. These temperatures decrease along with the increased distance from the mur neutralisant from a mean value of $23^{\circ} \mathrm{C} 1 \mathrm{~m}$ from the mur neutralisant to a value of $18.5^{\circ} \mathrm{C} 9 \mathrm{~m}$ from the mur, that is to say, at the far end of the room. Despite low winter temperatures, the fact that comfort temperatures are reached in the room with an active air chamber and relatively low airflows (for heating in winter), gives some idea of the energy efficiency of the mur neutralisant as a heating system.

In summer conditions, represented by one of the hottest days of the representative climate year in Paris, with outdoor temperatures which on one day oscillate between $17{ }^{\circ} \mathrm{C}$ and $30{ }^{\circ} \mathrm{C}$, the airflow temperature in the chamber decreases to values between $18.2^{\circ} \mathrm{C}$ and $15.6^{\circ} \mathrm{C}$. The increase in solar radiation entails less thermal uniformity throughout the day compared with the winter day at the same distance from the mur neutralisant, although the difference in the middle of the room $\left(5 \mathrm{~m}\right.$ from the mur neutralisant) is $1.7^{\circ} \mathrm{C}$. The difference in temperature with respect to the distance from the mur neutralisant is more pronounced, with mean values ranging from $22{ }^{\circ} \mathrm{C}$ at a distance of $1 \mathrm{~m}$ from the mur neutralisant to $18.5^{\circ} \mathrm{C}$ at $9 \mathrm{~m}$ from the mur, values potentially equivalent to those obtained in winter for the same distances. This demonstrates the potential of the thermal system which results in thermal uniformity at the same distance from the mur neutralisant throughout the year. As in the case of the heating operation mode, the relatively low airflow and relatively low airflow temperatures (for cooling in summer) show the energy efficiency of the mur neutralisant as a cooling system.

Therefore, the operating conditions of the mur neutralisant and the indoor temperature values obtained in both winter and summer confirm that the active thermal system proposed by Le Corbusier for controlling indoor temperatures makes it possible to obtain an isothermique thermal environment with similar indoor comfort conditions throughout the year, regardless of outdoor temperature and solar radiation. The energy efficient integrated system of temperature control was incorporated into the building envelope. This comprehensive interpretation of the relationship between architecture and energy was practically half a century ahead of environmental control systems with active façade systems designed with a view to building sustainability and energy efficiency. Had the mur neutralisant been executed following the original designs of Le Corbusier and Lyon, it would probably have posed serious competition to the air conditioning systems developed in the 20th century with great success and barely any technological competition.

\section{Acknowledgements}

The authors wish to thank the Le Corbusier Foundation and researcher Jorge Torres from Universitat Politècnica de València for the information and documentation provided for this study.

\section{References}

Brian Brace, T. "Le Corbusier, the city of refuge, Paris 1929-33". Chicago: University of Chicago Press. 1987.

Bryan, Harvey. "Le Corbusier and the 'Mur Neutralisant': An Early Experiment in Double Envelope Construction". Proceedings of the Ninth International PLEA Conference. 1991. pp. 257-62. 
Cuadernos de Postgrado. La respuesta de la American Blower Corporation. 24 January 1930.

FreeFem++ v.-3.37-1. Available from: http://www.FreeFem.org/ff++/ (22.05.15).

Ismail, K.A.R.; Henríquez, J.R. "Modeling and simulation of a simple glass window". Solar Energy Materials \& Solar Cells. 2003. 80. pp. 355-374.

Ismail, K.A.R.; Henríquez, J.R. "Simplified model for a ventilated glass window under forced air flow conditions". Applied Thermal Engineering. 2006. 26. pp. 295-302.

Ismail, K.A.R.; Henríquez, J.R. "Two-dimensional model for the double glass naturally ventilated window". International Journal of Heat and Mass Transfer. 2005. 48. pp. 461-475.

Le Braz, J. "La transmission de la chaleur gràverâ travers le verre: Des idées nouvelles sur le chauffage des habitations". Glaces et Verres. 1933. 20. pp. 13.

Lebel H.; Le Barbier, M. Société Anonyme des Manufactures des Glaces et Produits Chimiques de SaintGobain, Chauny et Cirey. Note sur la seconde série d'essais effectués pour la mesure de la transmission de la chaleur à travers les glaces à l'Annexe du Comptoir de Vente, 23 rue Boucry, Paris du 23 Novembre au 21 Décembre 1931. Letter of 11 March 1932.

Lebel, H.; Le Barbier, M. Société Anonyme des Manufactures des Glaces et Produits Chimiques de SaintGobain, Chauny et Cirey. Note sur les essais de transmission de la chaleur à travers les glaces, efectués à l'Annexe du Comptoir de Vente, 23 rue Boucry, Paris du 3 Avril au 8 Mai 1931. Letter of 25 June 1931.

Ramírez Balas, C.; Fernández Nieto, E.D.; Narbona Reina,G.; Sendra, J. J.; Suárez, R. "Numerical simulation of the temperature evolution in a room with a mur neutralisant. Application to 'The City of Refuge' by Le Corbusier". Energy and buildings. 2015. 86. pp. 708-722. 